\title{
Recent Trends in Large Hardwoods in the Pacific Northwest, USA
}

\author{
Jonathan W. Long ${ }^{1, *}$, Andrew Gray ${ }^{2}$ and Frank K. Lake ${ }^{3}$ \\ 1 USDA Forest Service Pacific Northwest Research Station, Davis, CA 95618, USA \\ 2 USDA Forest Service Pacific Northwest Research Station, Corvallis, OR 97331, USA; agray01@fs.fed.us \\ 3 USDA Forest Service Pacific Southwest Research Station, Arcata, CA 95521, USA; franklake@fs.fed.us \\ * Correspondence: jwlong@fs.fed.us; Tel.: +1-530-759-1744
}

Received: 1 September 2018; Accepted: 10 October 2018; Published: 19 October 2018

\begin{abstract}
Forest densification, wildfires, and disease can reduce the growth and survival of hardwood trees that are important for biological and cultural diversity within the Pacific Northwest of USA. Large, full-crowned hardwoods that produce fruit and that form large cavities used by wildlife were sustained by frequent, low-severity fires prior to Euro-American colonization. Shifts in fire regimes and other threats could be causing declines in, large hardwood trees. To better understand whether and where such declines might be occurring, we evaluated recent trends in Forest Inventory and Analysis (FIA) data from 1991-2016 in California and southern Oregon. We included plots that lay within areas of frequent fire regimes during pre-colonial times and potential forest habitats for fisher, a rare mammal that depends on large live hardwoods. We analyzed changes in basal area for eight hardwood species, both overall and within size classes, over three time periods within ecoregions, and in public and private land ownerships. We found the basal area to generally be stable or increasing for these species. However, data for California black oak suggested a slight decline in basal area overall, and among both very large trees and understory trees; that decline was associated with fire mortality on national forest lands. In addition, mature trees with full crowns appeared to sharply decline across all species. Many trends were not statistically significant due to high variation, especially since more precise data from remeasured trees were only available for the two most recent time periods. Continued analysis of these indicators using remeasured trees will help to evaluate whether conservation efforts are sustaining large, full-crowned trees and their associated benefits.
\end{abstract}

Keywords: forest restoration; wildfire; biological diversity; cultural diversity; ecosystem services; monitoring; indicators; inventory; Native Americans; non-timber forest products

\section{Introduction}

Forests in the Pacific Northwest of USA are generally dominated by and renowned for conifer trees, but hardwoods are still important, distinctive components of forests in the region [1]. Several of these species, including California black oak, Oregon white oak, tanoak, canyon live oak, giant chinquapin, Pacific madrone, bigleaf maple, and California laurel, form large and old trees. The importance of oaks and other hardwood trees has been recognized in the forests of eastern North America, where hardwoods are often dominant [2]. Research has highlighted the importance of hardwood communities for sustaining biological and cultural diversity in Pacific Northwest, while suggesting that changes in forest management policies and practices may be needed to stave off their declines [3-5].

\subsection{Background on the Potential for Hardwood Declines}

Since Euro-American colonization, the forests in the region have changed significantly, due to timber harvest, fire suppression, introduced pathogens, and climate change [6-8]. During the past 
century, timber production on both public and private lands prioritized conifers over hardwood trees. In the mid-20th century, softwood producers poisoned large tanoak and other hardwoods using the "hack-and-squirt" technique to favor the regeneration of conifer trees [6,8]. Large hardwood trees may have already declined from the pre-colonial era as Euro-American settlers cut tanoak for tanneries, and oaks and chinquapins for fuel and lumber [6]. Climate vulnerability analyses have projected that hardwood species such as black oak, tanoak, and maple are likely to expand their ranges under the warmer and more fire-prone conditions that are expected $[9,10]$. However, recent studies have highlighted how changes in fire regimes, including fire suppression and reduction of Native American influence, combined with large, severe, and recurring wildfires, could trigger declines in large hardwoods in both woodland [11] and forest areas [12,13]. In addition, the introduced pathogen Phytophthora ramorum, has caused hardwood mortality (described as "sudden oak death") within coastal forests of Northern California and southwestern Oregon [14], although climatic constraints, eradication and containment efforts have helped to mitigate its spread.

Declines in large hardwoods may jeopardize benefits, also known as ecosystem services, particularly for several rare wildlife species [15] and for Native Americans. Tribes in the region value many of these hardwood species for food, medicine, implements, construction materials, and other applications $[5,16,17]$. Village sites are commonly associated with groves of these hardwood trees $[18,19]$. Large trees had special cultural and spiritual significance as gathering places [19] and sacred trees [20]. Native Americans used large cavities in many of these species as shelters and as closets to store ceremonial items, food, firewood, and tools [20,21]. Because of the importance of hardwoods for sustaining traditional cultural values, tribes have initiated efforts to restore groves of these species based upon tribal traditional practices (Figure 1).

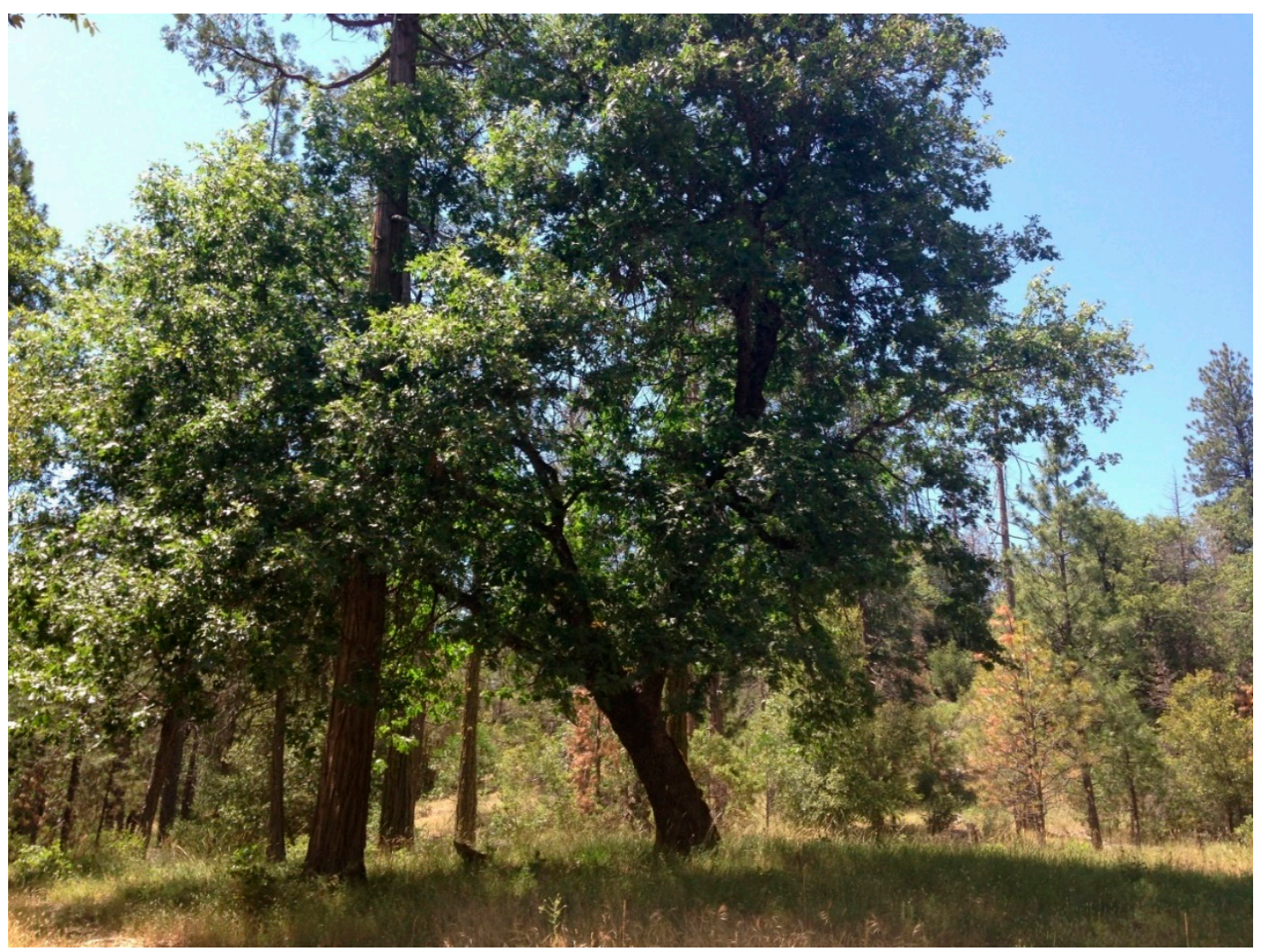

Figure 1. The North Fork Mono Tribe has been using thinning, burning, and other treatments to restore meadows with large California black oaks on the Sierra National Forest, and to promote desired qualities including low, broad crowns to facilitate the production and gathering of acorns (Photo credit: Ron Goode). 
Fruits of the eight hardwood species are consumed by a variety of wildlife species, and the hard nuts produced by oaks, tanoak, and chinquapin are particularly important because they can persist as a winter food source. Cavities and platforms in large hardwoods are also especially important as habitat for resting and raising young by fishers (Pekania pennanti), spotted owls (Strix occidentalis caurina and S. o. occidentalis), and great gray owls (Strix nebulosa nebulosa and S. n. yosemitensis) [22,23]. Research in many parts of the world have highlighted the importance of large trees that form cavities or "hollows" that are essential for some wildlife species [24].

High-intensity fires kill the above-ground stems of these hardwoods, even of mature trees, or otherwise causes damage that leads to their demise. Even in stands where hardwood trees are growing larger, which should afford greater resistance to fire, forest structure and fuel conditions may still be increasing their vulnerability to top-kill. As recent examples, the Poomacha Fire of 2007 led to the toppling of a giant canyon live oak on Palomar Mountain near San Diego within the following year [25], and the Soberanes Fire of 2016 felled the national champion madrone in the Big Sur area of coastal California [26].

These hardwood species are generally resilient to wildfire because top-killed trees typically resprout quickly. Consequently, high severity fires can facilitate a resurgence of hardwoods in areas where conifers have become dominant [27]. Because of this response, some proponents contend that active management is not needed to conserve hardwoods. For example, Baker [28] contended that shifts from open, hardwood-dominated conditions to more closed, conifer-dominated conditions reflects gradual forest recovery that occurs naturally over centuries, and then is reset by high-severity fires. Successional dynamics based upon infrequent, severe wildfires might be expected, particularly in areas that were sheltered from more frequent wildfires by chance, topography, and reduced Native American influence. Some wildlife biologists who are concerned with sustaining rare species, such as spotted owls and fishers, have also opposed the removal of conifers around oaks [8]. However, the combination of fire suppression punctuated by large, intense wildfires may be detrimental to sustaining legacy groves of large hardwoods and the services they provide [11]. Stand-replacing wildfire provides a slow and uncertain pathway for restoring mature hardwoods, particularly as some areas experience reburn well before hardwoods can mature [13].

Representing an alternative strategy, managers have proposed active management treatments to encourage the conservation and restoration of large legacy hardwood trees. Many scientists and tribes have recommended interventions to restore hardwood communities and to counteract the forest densification associated with fire suppression $[8,29]$. Such perspectives are rooted in the understanding that very frequent fires (reoccurring within 15 years) occurred prior to Euro-American colonization in many forest areas due to combinations of natural ignitions and burning by Native Americans [30,31]. Such a frequent fire regime killed small trees, resulting in more open forests with large individual trees, according to accounts by early scientists such as Jepson [6] and Native Americans [8,32] in the region.

\subsection{Need for Current Trend Analysis}

To understand whether declines in large hardwoods is a significant concern that warrants interventions, it is important to consider both recent and longer-term trends. Historical datasets tend to have many limitations for evaluating hardwoods in general, and large trees in particular [8]. However, in more recent decades, the USDA Forest Service's Forest Inventory and Analysis (FIA) program has provided standardized data across all ownerships in the United States. Studies in forests of eastern North America have found that alterations of frequent fire regimes, including the reduction of Native American influences, have led to declines in oaks [33]. An analysis of FIA data from the eastern USA highlighted concerns for oak decline from reports that intermediate-size oaks were not sufficient to replace dominant and co-dominant trees [2].

Several studies in the eastern United States have specifically used FIA data to evaluate the potential for nontimber forest products (NTFPs) that are important to tribes [34]; one study of ginseng evaluated changes in the volume of hardwood trees ( $>12.7 \mathrm{~cm}$ diameter at breast height (DBH)) [35], 
while another used specially collected measurements of birch bark to target the resource availability for tribal use [36]. However, the analysis of FIA data to evaluate NTFPs in the western United States has largely been limited to describing the occurrence of common understory plants of interest to harvesters [37], although a recent inventory report also noted that tanoak was the most abundant of NTFP species in California [38].

In California, studies have suggested that densities of hardwood trees, based upon recent FIA data, have not declined in general, compared to conditions reported in the 1930s surveys of forest vegetation led by Albert Wieslander. For example, McIntyre et al. [39] found that that period may have been a low point for hardwoods, which was followed by increases into the late 20th century. Dolanc et al. [40] found that madrone, maple, tanoak, and canyon live oak all increased in their frequencies of occurrence in plots from the 1930s to the early 2000s, while black oak slightly decreased. Among species that were more abundant, they found that tanoak, canyon live oak, and black oak had significantly increased in density, specifically among trees $10.2-60.9 \mathrm{~cm}$ DBH, while the density of larger trees was stable. Within Yosemite National Park, Lutz et al. [41] compared data from 1930s Wieslander plots to plots that were resampled by the National Park Service in the 1990s. They found that large $(>31 \mathrm{~cm} \mathrm{DBH})$ black oaks and canyon live oaks were $57 \%$ and $98 \%$ more dense in the $1990 \mathrm{~s}$, although those differences were not statistically significant. Maple and laurel trees (>10 cm DBH) both declined during that period, but they were uncommon in both periods, as were any very large $(>61 \mathrm{~cm}$ $\mathrm{DBH}$ ) hardwoods. Recently, Zielinski and Gray [42] reported that the resting habitat for the fisher had not declined, based upon FIA data and two models of fisher habitat that considered hardwoods; their southern Sierra model included the mean DBH of all hardwoods [43], while their northwestern California model included the total hardwood basal area per unit area [44]. A summary of FIA data from 1981 to 2000 by Waddell and Barrett [45] found that in California, there were significant increases in net growth for black oak, white oak, maple, laurel, madrone, and tanoak. Altogether, these previous studies of inventory data did not point to hardwood declines.

However, a targeted study of potentially more sensitive indicators could reveal important patterns for particular species or within particular areas. Recently, Long et al. (2017) reported recent declines in black oak biomass on national forest lands in California, in association with fire mortality. Recognizing the importance of black oaks in terms of tribal use and for fishers, a draft revision of the management plan for the Sierra National Forest proposed the abundance of large and full-crowned black oaks as a monitoring indicator [46]. Those recent developments suggested a need to further explore trends in large hardwoods.

\subsection{Objectives and Scope}

Our overall research question was whether these hardwood species were exhibiting a decline in large trees that might reduce the benefits for Native American tribes and rare species such as the fisher. We addressed this question by analyzing trends in recent forest inventory data within a region of Southwest Oregon and California where declines might be expected due to shifts in fire regime and where results are most relevant to fisher conservation. Pure hardwood stands in lower elevation woodlands are important for tribes and wildlife, including owls, but not for fishers. Our analysis explores trends as new inventory data have become available. However, we did test the hypotheses that we identified, based upon a review of relevant literature.

\section{Materials and Methods}

\subsection{Literature Review to Select Indicators}

We briefly reviewed scientific literature that describes the values of large hardwoods for Native Americans and wildlife, as well as previous research into the threats and trends for such trees. Such a review serves to identify the indicators and geographic factors that are important to consider in evaluating the trends over this broad region. Table 1 summarizes the information that is gleaned 
from the review, including the maximum tree size and age, the typical age of fruit production, shade tolerance, fire tolerance, and vulnerability to P. ramorum. We focus on the eight hardwood species, because they can occur frequently as large trees ( $>20 \mathrm{~m}$ tall and $>100 \mathrm{~cm} \mathrm{DBH})$ in mixed-conifer forests, and they can live for several centuries. We did not include species that are generally limited to small trees ( $<20 \mathrm{~m}$ tall) such as Pacific dogwood (Cornus nuttallii) and California hazelnut (Corylus cornuta). We also did not include tall species that are more typically short-lived, grow in riparian areas, and regenerate following floods or stand-replacing fires, such as black cottonwood (Populus trichocarpa), red alder (Alnus rubra), or aspen (Populus tremuloides).

Table 1. Hardwood species included in the analysis and attributes related to size, age, and disturbances.

\begin{tabular}{|c|c|c|c|c|c|c|c|c|}
\hline Scientific Name & $\begin{array}{c}\text { Arbutus } \\
\text { menziesii }\end{array}$ & $\begin{array}{l}\text { Quercus } \\
\text { garryana }\end{array}$ & $\begin{array}{c}\text { Quercus } \\
\text { kelloggii }\end{array}$ & $\begin{array}{c}\text { Acer } \\
\text { macrophyllum }\end{array}$ & $\begin{array}{l}\text { Chrysolepis } \\
\text { chrysophylla }\end{array}$ & $\begin{array}{c}\text { Notho-lithocarpus } \\
\text { densiflorus }\end{array}$ & $\begin{array}{c}\text { Quercus } \\
\text { chrysolepis }\end{array}$ & $\begin{array}{c}\text { Umbellularia } \\
\text { californica }\end{array}$ \\
\hline Species code & ARME & QUGA & QUKE & $A C M A$ & $\mathrm{CHCH}$ & NODE & $\mathrm{QUCH}$ & $U M C A$ \\
\hline Common name & $\begin{array}{l}\text { Pacific } \\
\text { madrone }\end{array}$ & $\begin{array}{l}\text { Oregon } \\
\text { white oak }\end{array}$ & $\begin{array}{l}\text { California } \\
\text { black oak }\end{array}$ & bigleaf maple & $\begin{array}{c}\text { giant } \\
\text { chinquapin }\end{array}$ & tanoak & $\begin{array}{l}\text { canyon } \\
\text { live oak }\end{array}$ & California laurel \\
\hline $\begin{array}{l}\text { Upper DBH } \\
(\mathrm{cm})\end{array}$ & 122 & 246 & 274 & 338 & 244 & 277 & 330 & 404 \\
\hline $\begin{array}{l}\text { Upper height } \\
(\mathrm{m})\end{array}$ & 38 & 37 & 40 & 49 & 46 & 63 & 30 & 53 \\
\hline $\begin{array}{l}\text { Upper age } \\
\text { (years) }\end{array}$ & 400 & 500 & 500 & 300 & 500 & $250+$ & 300 & $200+$ \\
\hline $\begin{array}{l}\text { Typical onset of } \\
\text { fruiting (years) }\end{array}$ & 30 & 20 & 30 & 10 & $<40$ & 30 & 20 & $30-40$ \\
\hline Shade tolerance & $\begin{array}{l}\text { intermediate } \\
\text { to low }\end{array}$ & low & low & high & intermediate & high & high & intermediate \\
\hline Fire tolerance & 1 & 2 & 2 & 1 & 1 & 1.5 & 0.5 & 0.5 \\
\hline $\begin{array}{l}\text { Vulner-ability to } \\
\text { Phytophthora } \\
\text { ramorum }\end{array}$ & mortality & $\begin{array}{c}\text { not } \\
\text { affected }\end{array}$ & mortality & $\begin{array}{c}\text { no mortality; } \\
\text { infection is limited } \\
\text { to leaf spots }\end{array}$ & mortality & mortality & mortality & $\begin{array}{l}\text { no mortality; } \\
\text { infection is } \\
\text { limited to leaf } \\
\text { spots }\end{array}$ \\
\hline
\end{tabular}

Notes: The ages of fruit production are referenced in McDonald and Tappeiner [47] and species profiles in the Fire Effects Information System (FEIS) [48-53]. Maximum age, height, and diameter at breast height (DBH) are from Niemiec et al. [54], except for canyon live oak, which is derived from Tollefson [49]; extraordinary specimens exceed such maximums. Fire tolerance codes, derived from the FEIS species profiles, are: 2 = moderate and large trees typically survive moderate-severity fires, $1.5=$ large trees only usually survive moderate-severity fires, $1=$ large trees sometimes survive moderate-severity fires, $0.5=$ large trees rarely survive even moderate-severity fires without top-kill. Information on vulnerability to Phytophthora ramorum, which causes sudden oak death, is from Waddell and Barrett [45] and Frankel [55].

\subsubsection{Species Distribution}

The eight species occur throughout much of northwestern California and southwestern Oregon. Bolsinger [56] reported that all of these species except giant chinquapin were "major" hardwood species on timberlands in California. All eight occur in the Sierra Nevada, but four of them (giant chinquapin, white oak, madrone, and tanoak) have small and patchy distributions. On the other hand, black oak, canyon live oak, laurel, and maple are distributed throughout the Sierra Nevada and into southern California (Figure 2). Black oak and canyon live oak are two of the most dominant contributors of biomass to California forests [45].

\subsubsection{Indicators for Fruit Production}

The nut-bearing oaks and tanoaks do not typically produce fruits until at they are at least 20-30 years old, whereas maple and madrone bear fruit earlier (Table 1). However, at least several of these species are capable of producing relatively small quantities of fruit in resprouted stems within six years, as reported for black oak, tanoak, madrone, and chinquapin [47,59]. As a general rule for these species, trees that produce fruits in high quantity are many decades old (requiring more time to mature than many competing conifer species) and have full crowns due to growth in open conditions $[6,47,60]$. Some species may enter prime production after a century [47], although one study suggested that production in white oak may reach a plateau after only 60-80 years [60]. Acorn production in white oak is greatest in trees with full crowns and increased exposure to light, 
which may be described as a "mushroom-shape" that is marked by low, broad crowns [60,61] (Figure 1). Similar relationships between shape and nut productivity have been described for tanoak [6] and black oak [62]. Consequently, both basal area, as a proxy for age, and crown attributes are important indicators of productivity, while tree height and wood volume may be less important.
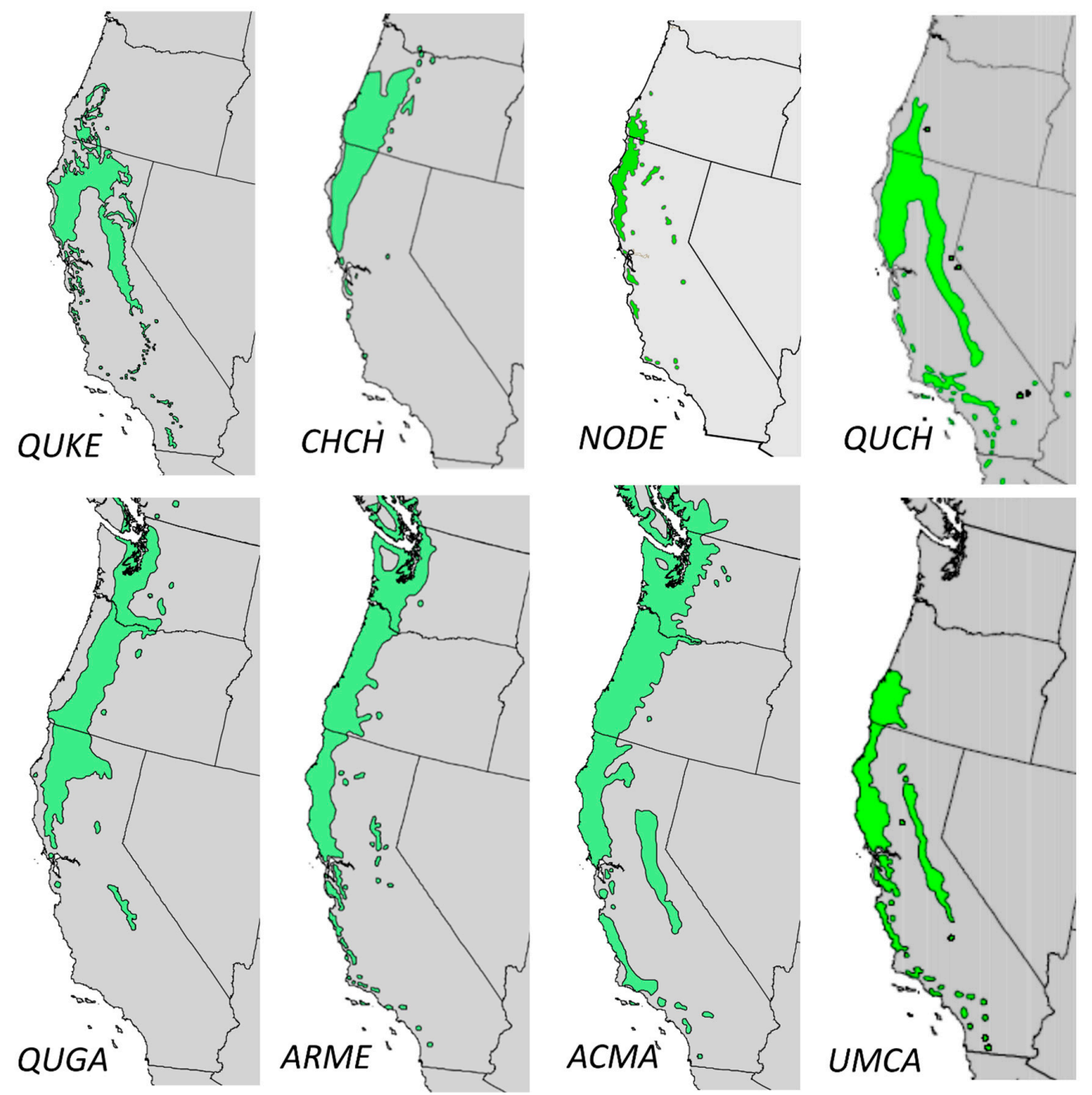

Figure 2. Distributions of the eight study species of hardwood trees within the far western USA from Little $[57,58]$.

\subsubsection{Indicators for Wildlife Habitat}

Studies of fisher habitat in the Pacific Northwest of North America have found that all eight of the hardwood species we analyzed are used by fisher, along with black cottonwood and aspen $[15,63]$. Live trees harbor $91 \%$ of the fisher dens found in hardwoods [15]. Trees used by fisher are also very large, as Yaeger [63] (whose study included all of the species except laurel) reported that the median diameter at breast height (DBH) of hardwoods used, primarily for resting, was $77.2 \mathrm{~cm}$ at the Hoopa Valley Indian Reservation (January 1996 to June 1998) and $63.5 \mathrm{~cm}$ on the Shasta-Trinity National Forest in northwestern California. Accordingly, Aubry et al. [64] found that basal area of live hardwoods 51-100 cm DBH was a useful predictor of habitat quality across the range of the fisher.

Owls, including both northern and California spotted owls and great gray owls, also use cavities in large hardwoods. For example, North et al. [65] reported that $11 \%$ of the California spotted owls on the Sierra National Forest on the Sequoia-Kings Canyon National Park nested in cavities in very large and old black oaks ( $91 \mathrm{~cm}$ mean DBH, >139 years old within the study). They also found that spotted owls built nests on platforms in somewhat smaller (mean $52 \mathrm{~cm} \mathrm{DBH}$ ) canyon live oak trees. A recent 
review [23] reported that great gray owls used hardwoods (mostly black oaks) with a mean DBH of $102 \mathrm{~cm}$, although six of the 16 oaks used for nesting were dead. Altogether, these studies suggest that basal area of large living hardwoods is an important indicator of wildlife habitat quality. While dead trees also have value for wildlife, sustaining large live hardwoods also ensures a supply of dead trees.

\subsubsection{Tolerance of Shade, Fire, and Phytophthora ramorum}

These species have complex interactions with each other and with conifers that are influenced by competition for light, fire effects, and disease. In the absence of disturbances such as wildfires, all of these hardwoods are succeeded by conifers, particularly white fir (Abies concolor) and Douglas fir (Pseudotsuga menziesii) [1,66]. The more shade-tolerant species, including tanoak, maple, canyon live oak, and giant chinquapin can become dominant in densifying forests that were formerly dominated by the more shade-intolerant species (Table 1). The eight species have variable resistance to fire depending upon their size (Table 1); fire generally kills small stems, but larger stems are able to survive low-intensity fires [67-69]. Lutz, van Wagtendonk and Franklin [41] noted that canyon live oak was much less common, and laurel was absent within burned plots in Yosemite National Park; such findings support the assignment of the lowest fire tolerance ratings for those species. The sudden oak death pathogen (P. ramorum) reportedly infects all of the species except white oak $[45,55]$. Laurel is very susceptible and facilitates spread of the disease; while chinquapin, madrone, canyon live oak, and black oak all have experienced mortality, the loss of large tanoak trees been one of the main impacts to ecosystems [70].

\subsection{Overview of Forest Inventory Data}

The FIA program measures environmental variables every 10 years in the western United States at sample points arranged in a hexagonal grid (with centers of hexagons $5.47 \mathrm{~km}$ apart for one point per 2400 ha) across all ownerships [71]. Individual trees are identified and measured on nested plots for different sized trees, and their status (live or dead), size, condition, and estimated cause of death are tracked over time [38]. When plots are sampled, disturbances that occurred between measurements are noted, including cutting, fire, cutting \& fire, and "other", which includes insect, disease, beaver, porcupine, bear, ice, wind, flood, and landslides. The disturbances noted for each plot did not necessarily result in mortality of hardwood species; for example, cutting could have involved removal of only conifers.

\subsection{Study Area}

The study area (Figure 3) encompasses forested lands in California and Oregon with dominant vegetation that ranges from oak (Quercus) and juniper (Juniperus) species at the dry end, to Douglas fir and California mixed conifer in mesic areas, to true fir (Abies) forests in subalpine areas [72]. We grouped areas of broadly similar vegetation and disturbance regimes within contiguous ecoregions [73]. This study area includes part of the range for both subspecies of spotted owls and great gray owl. We selected plots in areas characterized by a "frequent, low severity" fire regime [74] to focus on areas where shifts in fire regimes would be most prominent. We also confined the study area to potential habitats for the fisher, which we defined by adding a buffer of $5 \mathrm{~km}$ around areas that are designated as being "selected for" or "intermediate" (meaning neutral rather than "selected against") in a fisher habitat model [75]. The buffer accounts for the fact that the habitat model attempted to select mature stands based on remote sensing analysis, while our objective was to describe conditions within zones of potential habitat, regardless of the current forest condition. Although both fisher habitat and areas of frequent fire regime extend further north into Washington State, we excluded plots that were north of 43.7 degree latitude, which approximates the northernmost extent of the Klamath ecoregion. There were 9.15 million ha of forest land that met the study criteria, represented by 3971 plots that ranged in elevation from 15 to $2890 \mathrm{~m}$. 


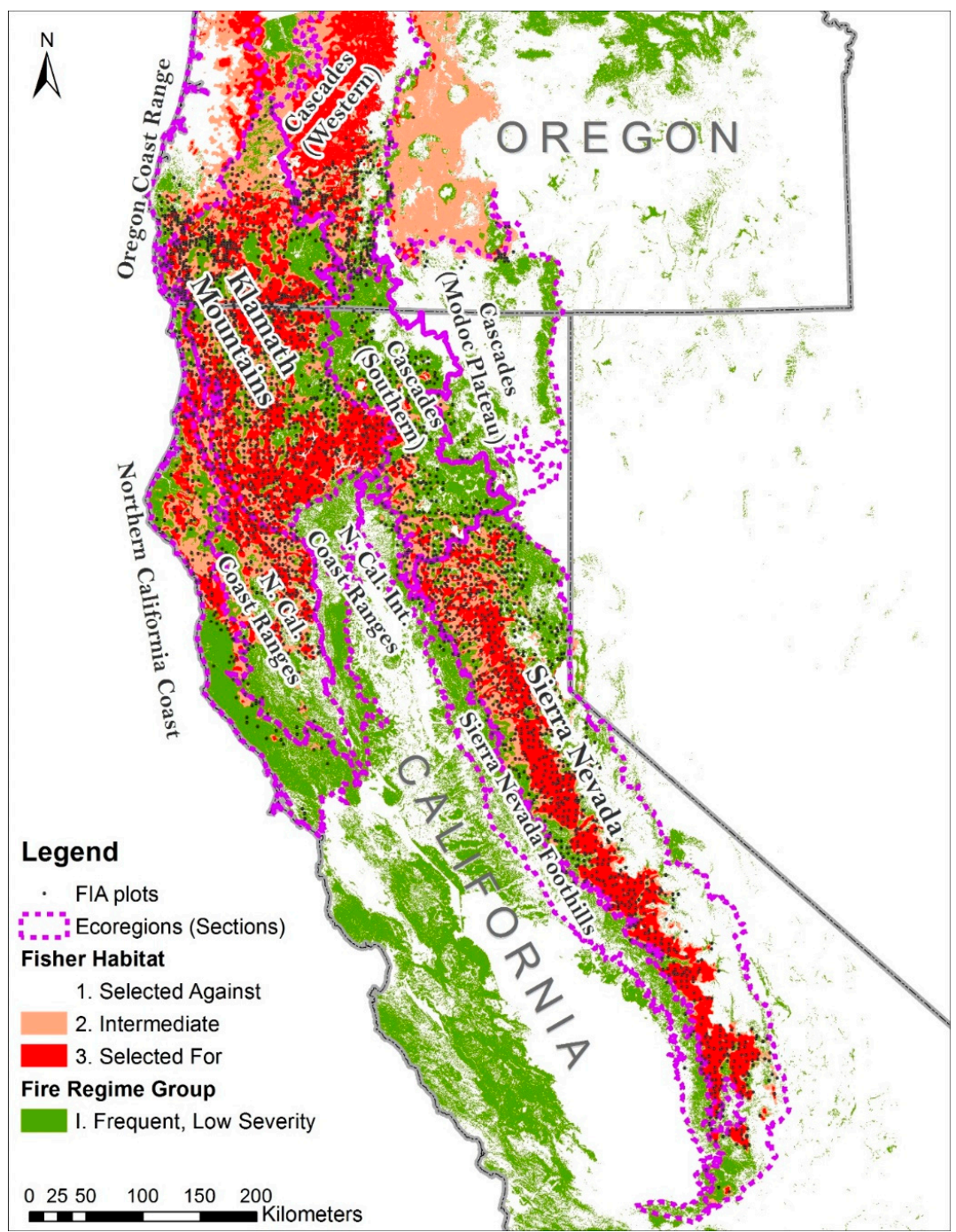

Figure 3. Map of the study area in California and Oregon, USA, showing ecoregions, areas of frequent, low severity fire regime, habitat for fishers, and the approximate location of the Forest Inventory and Analysis (FIA) plots that have at least one tree from the eight study species.

\subsection{Measurement Periods}

Three measurement periods were represented in the data. The first measurement period ("time 1") consisted of:

- the FIA periodic inventory of non-National Forest System (NFS) lands in California (1991-1994; mean 1992),

- the NFS inventory in California (1992 to 2000; mean 1998),

- the FIA periodic inventory of non-NFS lands in Oregon (1995-1998; mean 1997), and,

- $\quad$ the NFS inventory of Oregon (1993-1997; mean 1995).

The second remeasurement period ("time 2") installed an annual inventory on all lands where a tenth of the plots were expected to be measured every year in spatially-representative panels [71]. The first panel cycle for California and Oregon began in 2001 and ended in 2010, except in California on NFS lands, where the schedule was accelerated, to install all plots on NFS lands by 2006. The third period started in 2007 with remeasurements of plots that were established on the accelerated schedule on California NFS lands, while on other areas, remeasurements began a new panel cycle in 2011. The last year of data that was available and compiled for this study was 2016. Inclusion of the 
accelerated annual plots on California NFS lands ensured a full remeasurement sample of those lands. Overall, the mean measurement years for plots in the three inventory assessments were 1996, 2004, and 2012, for mean remeasurement intervals of 7.8 years between times 1 and 2, and 8.8 years between times 2 and 3. The periodic and annual data are available in a public database [76].

We analyzed results from the full set of annual plots in the study area and also for the subset of those that were included in the initial inventory at time 1 . The difference in basal area per unit area between those two sets at time 2 was added to the time 1 calculation. This adjustment is an estimate of the value at time 1 if we had measured the same set of plots as in the annual inventory. However, because the sample of other public lands was so different (there were no plots on other federal lands in California at time 1), the three-period comparisons were only made for NFS and private lands. Since the first period used a different plot design, comparisons across the three periods have higher variance and lower significance than the remeasurement from time 2 to time 3, which compared tree-to-tree change using the same plot design. The basal area per unit area is a better metric for comparing values across inventories than totals, because it avoids the confounding effects of definitional and sampling differences in the total area of forest land.

\subsection{Metrics and Hypotheses}

Based upon the review of potential indicators above, we hypothesized that declines in the basal area of large trees would be greatest in the shade-intolerant black oak and white oak, which depend on frequent fires. We expected madrone to follow that same pattern, while recognizing that it is less tolerant of fire and somewhat more tolerant of shade. We hypothesized that any declines would be even less in the five more shade-tolerant, fire-intolerant species-tanoak, canyon live oak, maple, giant chinquapin, and laurel—because those species may be favored by a longer fire regime and more shading. Furthermore, some of those species, such as canyon live oak, are often dominant on steep slopes that produce little fuel and burn less frequently than the surrounding landscape, so that they may be less affected by shifts in fire regimes [1].

Figure 4 summarizes the overall analysis approach and key variables used to filter and sort results. Because management goals and practices may differ among ownership categories, we stratified results between NFS lands, other public lands, and private lands (which includes tribal lands). Within public land areas, we considered both "reserved" areas, which have more restrictions on timber harvest (primarily wilderness, national and state parks, and national monuments), and "unreserved" areas. We expected more declines in the hardwood basal area due to cutting on private lands, and more declines due to natural disturbances, including fire, insects, and disease on public lands, particularly in "reserved" areas. However, we did not hypothesize that trends would necessarily be different across the ownership categories, particularly because such differences in management predate the inventory baseline. We also stratified results by ecoregions (Figure 4). Since we had already filtered the areas to include only areas of frequent fire regime, we did not have explicit expectations for variations among ecoregions, except that we expected that species vulnerable to mortality by $P$. ramorum would have declined in the California Coast ecoregion, where a quarantine had been imposed to constrain its spread [45].

We focused on live tree basal area per unit area as a primary response variable. We calculated means and variances using double sampling for post-stratification [77], and tested for differences based on the Z statistic, which is customary for inventory data where estimates based upon large sample sizes approach the normal distribution. We examined results with standard size classes ranging from sapling, small, medium, large, and very large trees (Figure 4). Based upon a simple linear regression between age and DBH reported for black oak in McDonald and Tappeiner [47], the breaks between these size classes would be equivalent to 30, 66, 149, and 185 years, respectively. Based upon the data for tanoaks from Sonoma County [78], those size class breaks would be equivalent to 46, 69, 114, and 137 years, respectively. 
We considered trends in crown condition because trees that are suppressed are more prone to mortality and less productive [58]. We therefore examined the crown condition class, which describes both overstory trees (classified as open-grown, dominant, or co-dominant) and understory trees (classified as intermediate or suppressed). Shifts in basal area from open, overstory trees, to suppressed understory trees could be a leading indicator of overall declines. Accordingly, we hypothesized that the basal area in medium-sized or larger trees $(>28 \mathrm{~cm} \mathrm{DBH})$ with full crowns (classified as open-grown or dominant), may have declined as forests became more dense. We also analyzed change in basal area within overstory versus understory trees within plots that were undisturbed, to help evaluate trends in general forest succession.

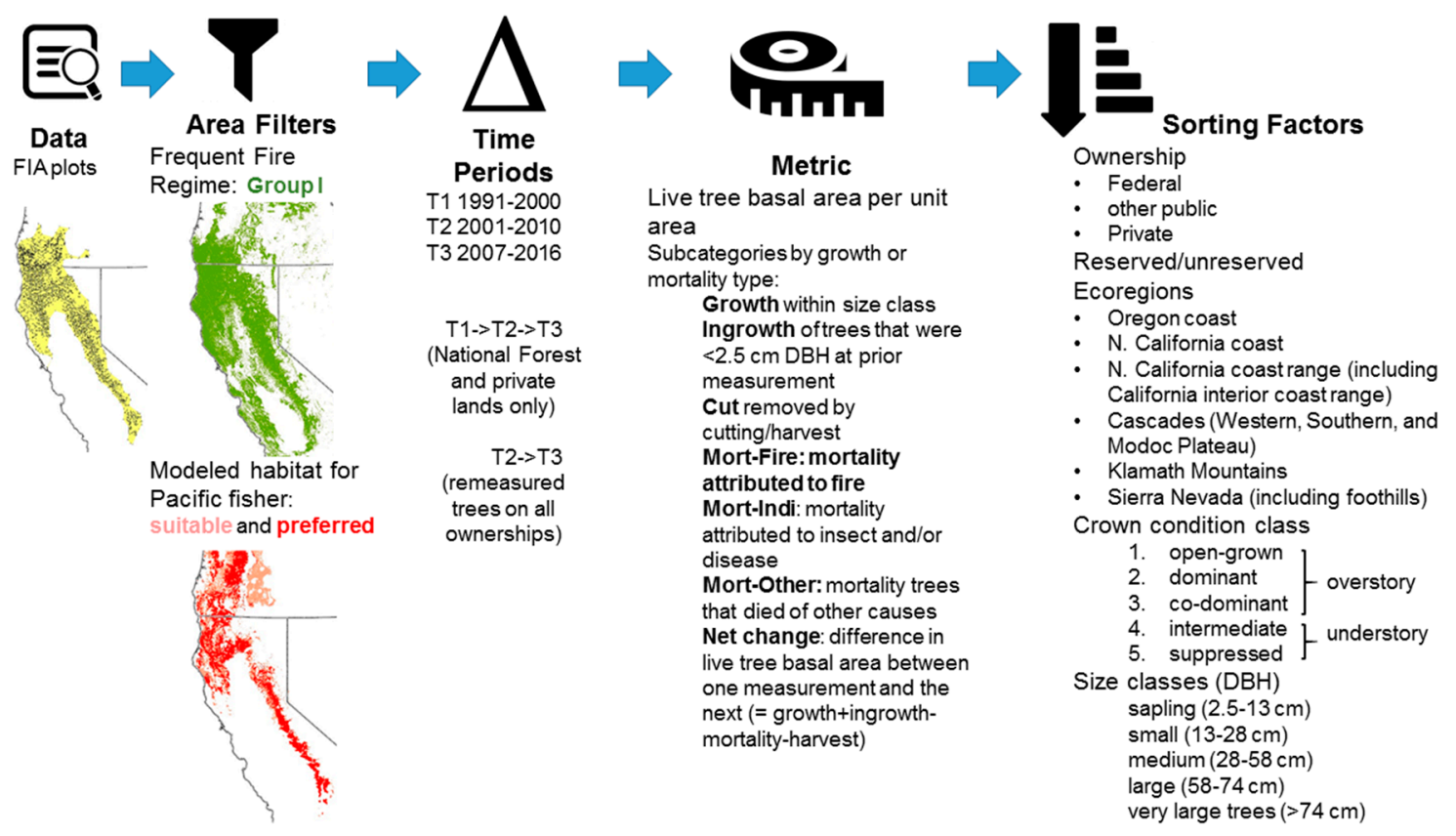

Figure 4. Schematic showing the factors considered in the trend analysis of large hardwoods.

\section{Results}

\subsection{Distribution of Basal Area and Rates of Disturbances across Ecoregions and Ownership Areas}

Table 2 shows the amount of study area within each ecoregion, as well as the amount of disturbance within each ecoregion. Over $40 \%$ of the basal area of the eight species was located in the Klamath ecoregion, with the Sierra Nevada (18.3\%), California Coast (17\%), and California Coast Range (16.6\%) ecoregions also being important. Other regions, including the Cascades (3.4\%) and Oregon Coast Range (2.8\%), had much less basal area of the species of interest. Basal area for each species across the ecoregions during time 2 is included in the Supplementary Materials (Table S1). Tanoak was the most dominant hardwood species in the coastal ecoregions, while black oak and canyon live oak were dominant in the Sierra Nevada. Other ecoregions were less dominated by one or two species, but tanoak, canyon live oak, black oak, and madrone were much greater contributors to the hardwood basal area (each contributing 13\%-30\% of combined basal area for the eight species) than the remaining four $(2 \%-6 \%$ of combined basal area).

Within the study area, $2.5 \%$ of forestland was disturbed each year, with cutting being the most prevalent disturbance, followed by fire (Table 2). The highest rate of fire disturbance in the selected forestlands was in the Klamath ecoregion at $1.6 \%$ /year, while the highest rate of cutting disturbance was in the Cascades ecoregion at $2.6 \%$ /year (Table 2). Over half of the study area (51.8\%) was managed by the NFS, $10.6 \%$ by other public agencies, and the remaining $37.6 \%$ was under private 
ownership. Sixteen percent of the forested area was on public lands "reserved" from management for timber production.

Table 2. Total area and annual rates of disturbance on forestlands in the study area between times 2 and 3 , by ecoregion

\begin{tabular}{ccccccccccccc}
\hline \multirow{2}{*}{ Ecoregion } & \multicolumn{2}{c}{ Total Area } & \multicolumn{2}{c}{ Fire } & \multicolumn{2}{c}{ Cut } & \multicolumn{2}{c}{ Fire + Cut } & \multicolumn{2}{c}{ Other } & \multicolumn{2}{c}{ Total Disturbed } \\
\cline { 2 - 13 } & ha & \% & ha/year & \% & ha/year & $\%$ & ha/year & ha/year & ha/year & \% \\
\hline Klamath & $3,037,602$ & 33 & 47,582 & 1.6 & 26,982 & 0.9 & 1928 & 0.1 & 2455 & 0.1 & 78,947 & 2.6 \\
CA Coast & 743,446 & 8 & 766 & 0.1 & 10,205 & 1.4 & 484 & 0.1 & 592 & 0.1 & 12,047 & 1.6 \\
CA Coast Range & 865,360 & 9 & 11,645 & 1.3 & 3043 & 0.4 & 0.0 & 0.0 & 1090 & 0.1 & 15,779 & 1.8 \\
OR Coast Range & 178,611 & 2 & & 0.0 & 2687 & 1.5 & 445 & 0.2 & 552 & 0.3 & 3684 & 2.1 \\
Sierra & $2,766,788$ & 30 & 26,437 & 1.0 & 31,994 & 1.2 & 4252 & 0.2 & 2511 & 0.1 & 65,194 & 2.4 \\
Cascades & $1,559,874$ & 17 & 5276 & 0.3 & 39,948 & 2.6 & 2626 & 0.2 & 3649 & 0.2 & 51,499 & 3.3 \\
Totals & $9,151,682$ & 100 & 91,706 & 1.0 & 114,859 & 1.3 & 9735 & 0.1 & 10,849 & 0.1 & 227,149 & 2.5 \\
\hline
\end{tabular}

\subsection{Overall Changes in Basal Area and Associated Causes of Mortality}

Most of the species appeared to increase modestly in basal area over the three time periods, except for slight, suggestive declines across periods for black oak and substantial increases for tanoak, canyon live oak and laurel from time 1 to time 2 (Figure 5). However, none of the changes were statistically significant because of wide variance, which in part reflects the smaller sample size and the lack of remeasured trees in the three-period analysis.

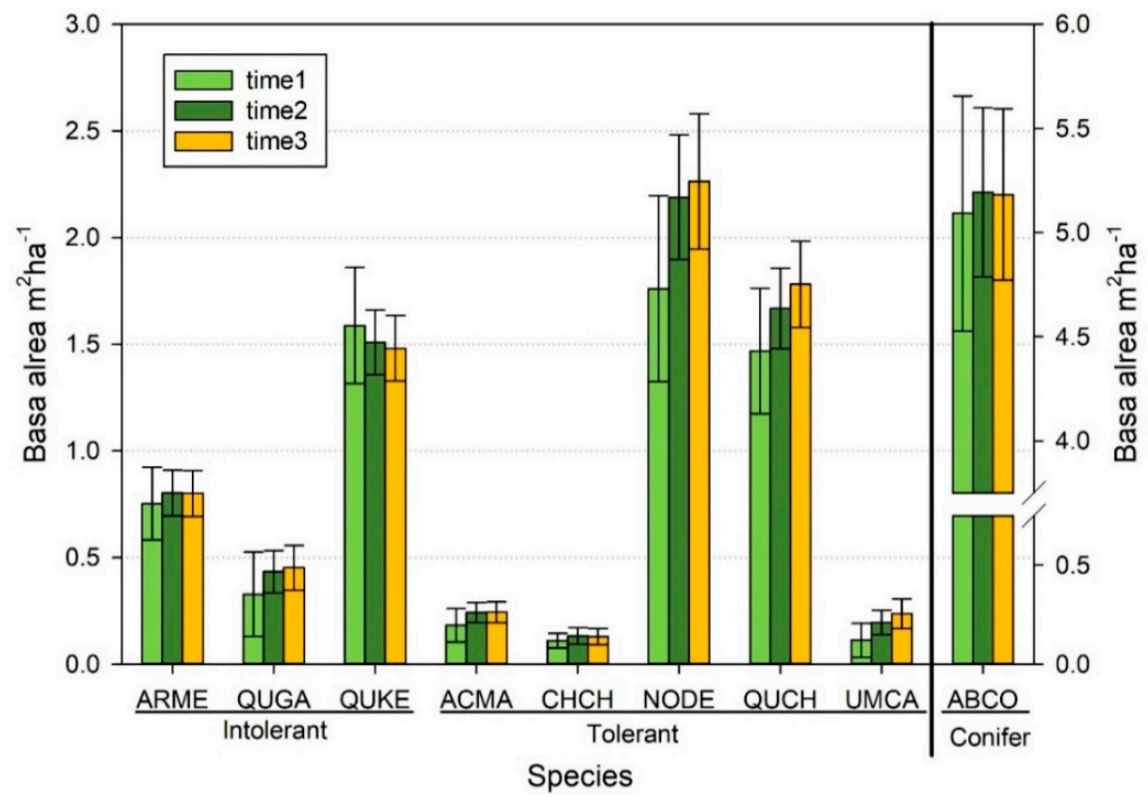

Figure 5. Species basal area across three time periods, National Forest System (NFS), and private lands only. Species codes are first two letters of genus and species, order of shade-intolerants on the left and shade-tolerants on the right used in all figures; white fir (a conifer) is shown for comparison using a second y-axis on the right. Error bars represent $95 \%$ confidence intervals.

The trends among remeasured trees across all ownerships from time 2 to time 3 were similar to those seen in the three-period analysis, with growth generally compensating for mortality (Figure 6, Supplemental Table S2). However, several species experienced statistically significant increases, including white oak $(+6.3 \%, p=0.003)$, tanoak $(+3.75 \%, p=0.041)$, canyon live oak $(+6.16 \%, p=0.002)$, and laurel $(+20.7 \%, p<0.001)$. Giant chinquapin registered a slight but statistically insignificant decline, while madrone and maple had small and statistically insignificant increases. White fir, a common conifer species included for comparison, showed a negligible increase $(0.34 \%, p=0.45)$. On the other hand, black oak experienced a relatively modest $(1.54 \%)$ and suggestive $(p=0.060)$ decline. 


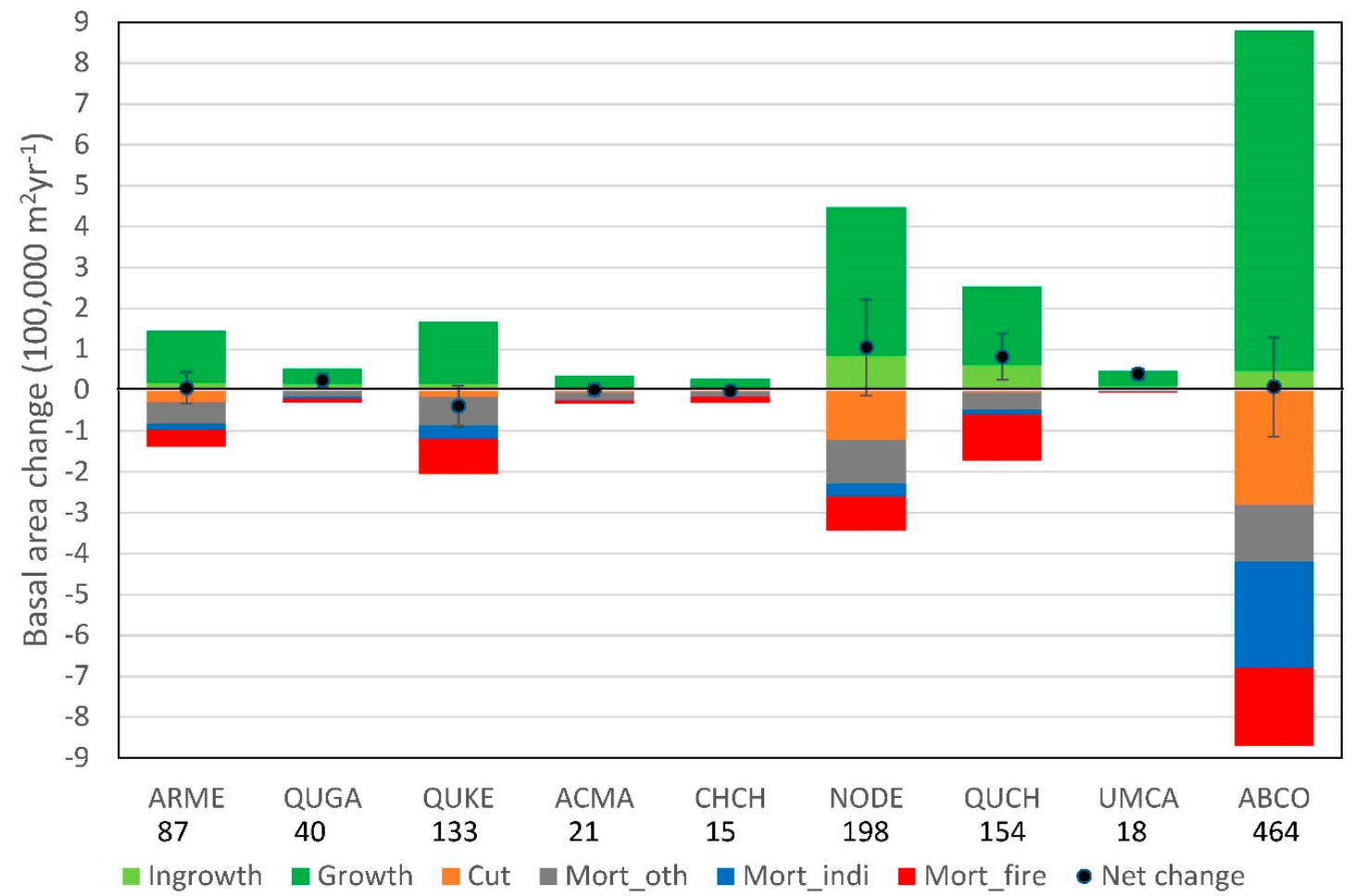

Figure 6. Overall change in basal area, and changes associated with particular causes of mortality (abbreviated terms in legend are defined in Figure 4), from time 2 to time 3 for eight hardwood species and white fir (ABCO). Number under species code is live basal area $\left(\times 100,000 \mathrm{~m}^{2}\right)$ at beginning of time 2 , and error bars on the net change values represent the $95 \%$ confidence interval.

Mortality was attributable to fire, cutting, insects/disease, and other causes for all species, although causes did vary somewhat by species. For example, mortality of individual black oak and canyon live oak trees was most commonly attributed to fire (Figure 6). By contrast, insects/disease and cutting were more important than fire for the common conifer, white fir (ABCO in Figure 6). Tanoak was the only hardwood species for which cutting was identified as the predominant cause of mortality. The rate of mortality associated with cutting was twice as high for tanoak ( $0.6 \% /$ year) as for any other species. However, the data did not indicate whether the cut tanoak were already dead or infected by $P$. ramorum. Although tanoak had high rates of cutting and natural mortality, its high rate of growth more than compensated. Within plots that were undisturbed, we found a significant loss of basal area for understory black oak, while overstory black oaks significantly increased in basal area; the basal area in overstory trees also increased for the other species, while the basal area in understory trees was maintained, or increased in the case of tanoak, canyon live oak, and laurel (Supplemental Figure S3).

\subsection{Changes in Basal Area within Size Classes}

When examining the results within particular size classes, the three-period comparison also suggested a steady decline in basal area of very large black oak, while very large madrone and tanoak exhibited substantial increases from time 1 to time 2 (Figure 7). However, in the remeasured data from time 2 to time 3, changes in the largest diameter classes were not apparent. The confidence intervals for net change for most of those estimates included zero change, although there was a significant net loss $(-0.91 \%)$ of small black oak (13-28 cm DBH). 


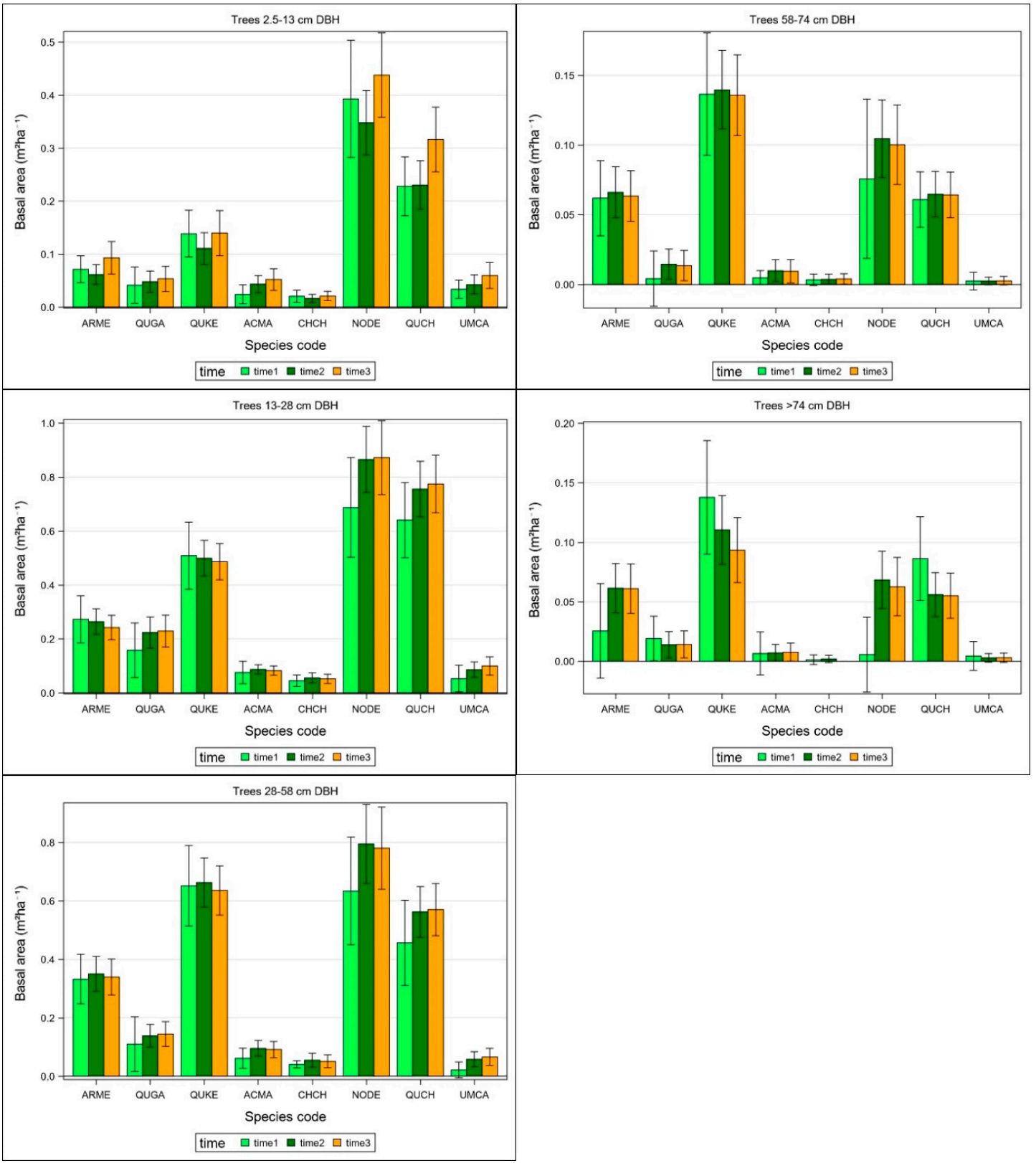

Figure 7. Species basal area by diameter class for three times with $95 \%$ confidence intervals (NFS and private lands only).

\subsection{Changes in Basal Area across Ecoregions and Ownership}

Within ecoregions, changes in basal area between times 2 and 3 (Figure 8) were generally consistent with those from the three-period analysis (Supplemental Figure S1). We focus on the two-period analysis, since several results were statistically significant, including increases in canyon live oak and laurel in the California Coast and California Coast Range, increases in tanoak in the California Coast Range, and increases in white oak in the Cascades. While not statistically significant, the average black oak basal area declined in the California Coast Range, Sierra Nevada, and Klamath, and much of those mortality in those areas was attributed to fire. Meanwhile, the mean basal area of black oak increased in the Cascades, where the fire mortality was relatively low. Other regions contributed little to the basal area of black oak. Tanoak basal area had a non-significant decline in the Oregon Coast, but generally was stable or increased, including a significant increase in the California Coast Range. Mortality of tanoak in the coastal regions was dominated by cutting rather than by disease or fire. 


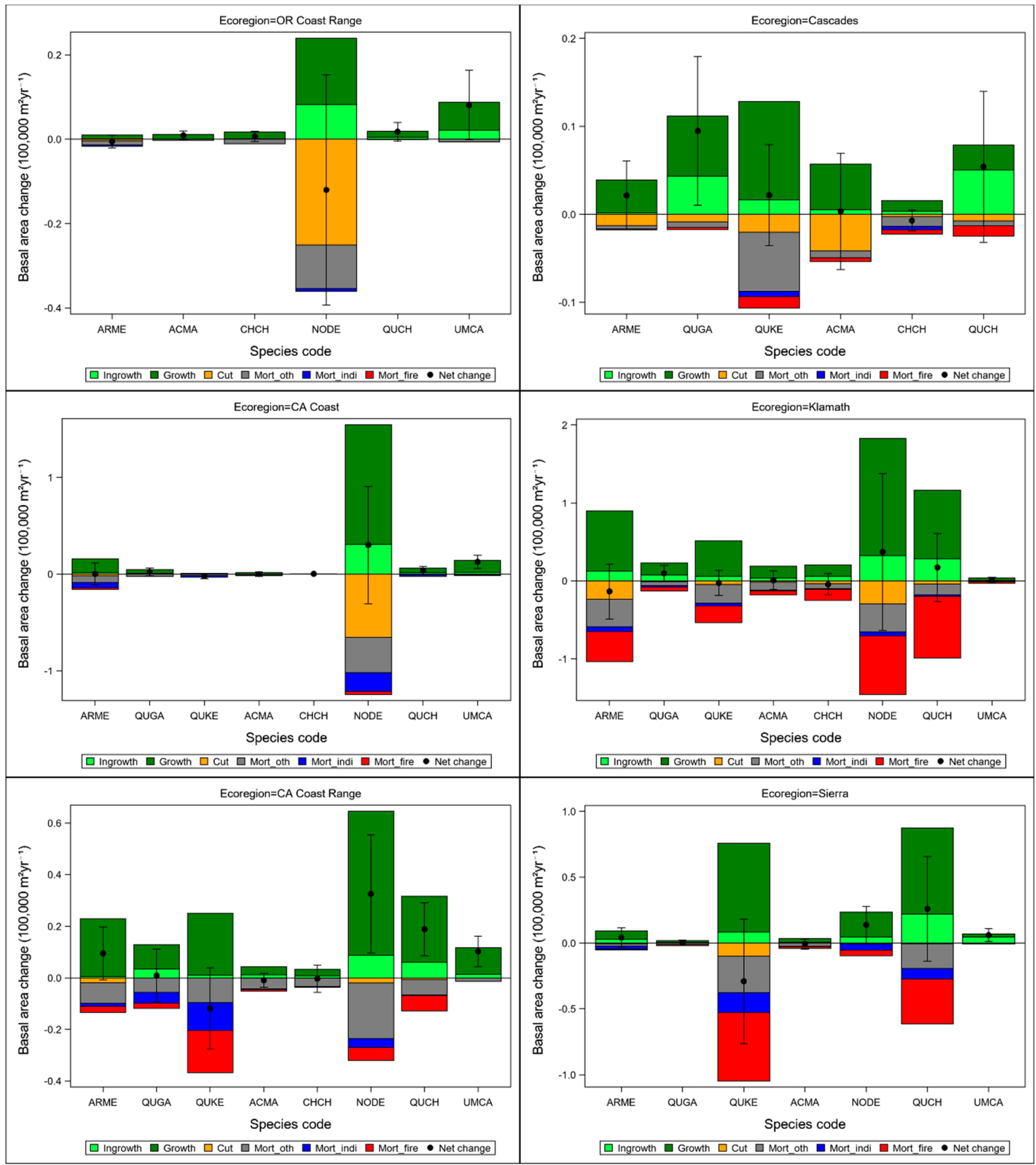

Figure 8. Basal area change by species by ecoregions with net changes shown by points with $95 \%$ confidence interval bars.

The analyses by ownership provides additional insights into trends. The three-period analysis did not reveal statistically significant trends and suggested overall stability, although shade-tolerant tanoak and canyon live oak tended to increase in NFS and private unreserved lands, while the shade-intolerant black oak and madrone tended to decline in reserved lands (Supplemental Figure S2). The two-period analysis (Figure 9) revealed similar patterns, although some trends were statistically significant, including a decline in madrone on NFS reserved lands, increases in white oak on non-federal public unreserved lands, and increases in white oak, canyon live oak and laurel on private lands. Results from that analysis also highlight variation in causes of mortality (Figure 9). On public lands, fire was a major cause of mortality, while cutting was fairly minor; the opposite relationship held on private lands. Six of the species (all but tanoak and laurel) tended to decline within NFS-reserved areas (although only the decline in madrone was statistically significant). Mortality in those areas was strongly associated with fire. Increases in hardwood basal area tended to be greater on NFS unreserved lands than on 
private lands, except for laurel. Black oak basal area tended to decline on NFS lands, in both reserved and nonreserved areas, but it was stable on other public and private lands.
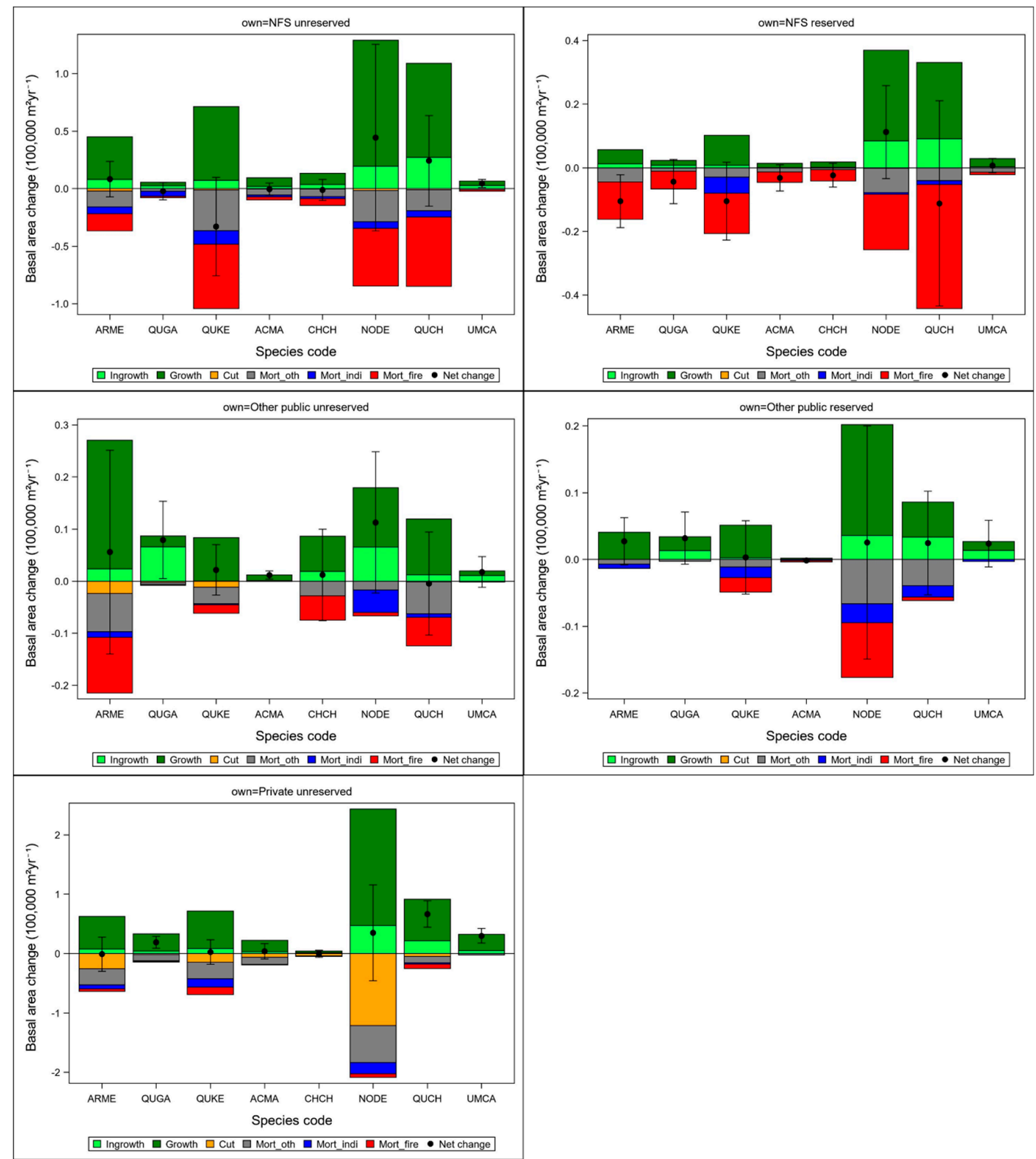

Figure 9. Basal area change by ownership and reserve status with net change shown by points with $95 \%$ confidence interval bars.

\subsection{Changes in Basal Area by Crown Condition Class}

Combined basal area of medium-sized and larger hardwoods $(>28 \mathrm{~cm}$ DBH) that were classified as either open-grown or dominant declined across all eight species (Figure 10). These declines were generally offset by corresponding increases in the co-dominant crown condition class, except in the case of black oak and maple. This shift was also evident for white fir, a dominant conifer, but it was not as pronounced as for the hardwoods. 


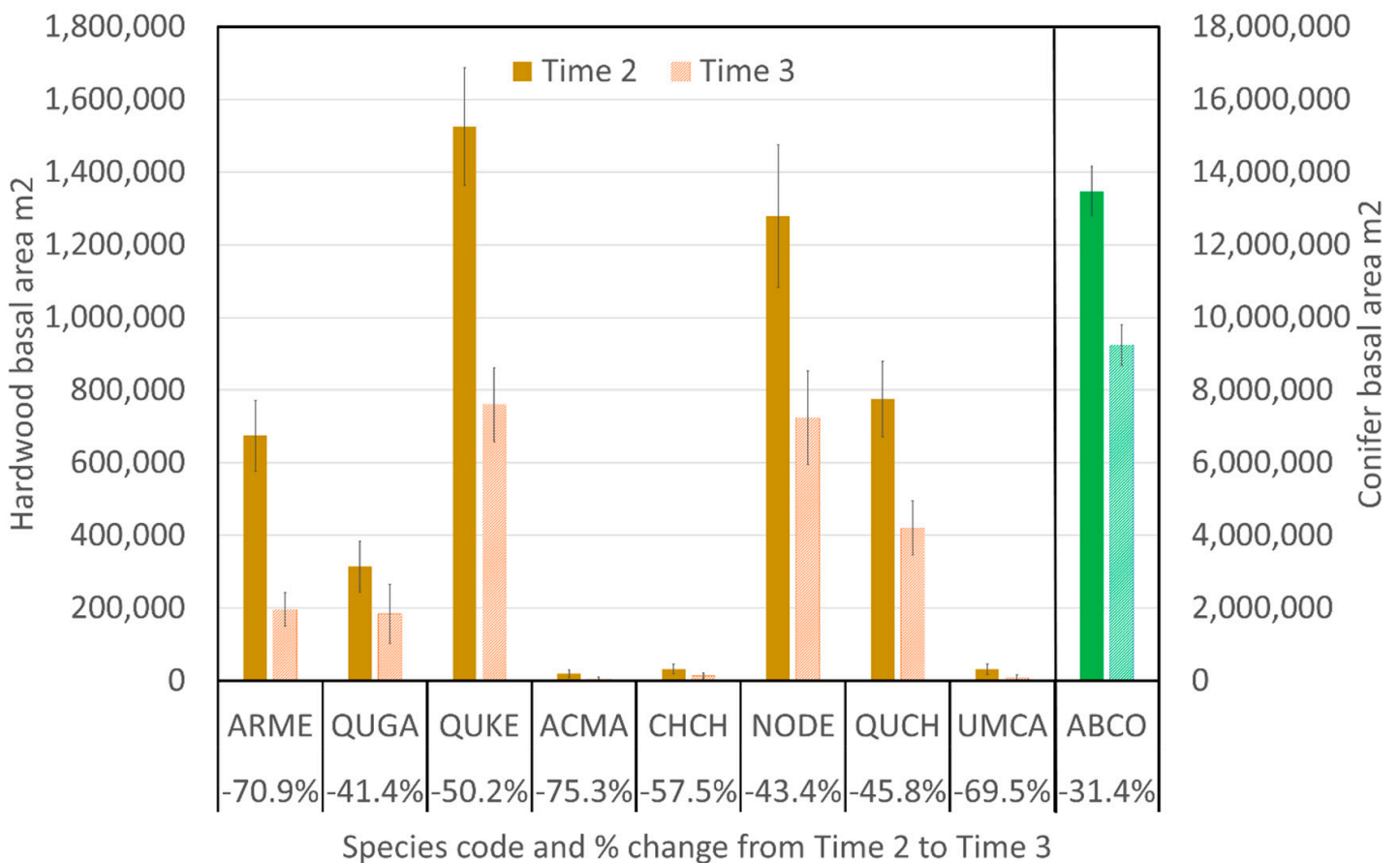

Figure 10. Basal area of trees $>28 \mathrm{~cm}$ DBH in the open-grown and dominant crown condition categories at times 2 and 3 for eight hardwood species and white fir (on the second Y-axis on the right), with percent reductions labeled (bars are $95 \%$ confidence intervals).

\section{Discussion}

\subsection{Overall Trends}

The eight species included in this analysis mostly exhibited stable or increased basal area, contrary to our hypothesis that they might be declining in the study region. We also did not find declines within the California Coast region, where P. ramorum has been causing hardwood mortality. Even though the FIA database is the best available information for determining trends over a large area, the power of these analyses is still limited, especially for species that are often minor forest components. Furthermore, by confining the analysis plots to frequent fire regime areas within suitable fisher habitat, important trends for particular species across their entire ranges may be missed. For example, impacts of $P$. ramorum will be more evident at lower elevations and latitudes along the coast compared to the areas of focus in this analysis.

Black oak stood out from the other seven species for experiencing downward trends in overall the basal area in the two-period comparison, and in the basal area of very large trees in the three-period comparison, although neither result was statistically significant, based upon a 95\% confidence level. Statistically significant declines were evident in small black oaks and those classified as understory trees. Our results also indicated that declines in black oak were more pronounced on NFS lands than on other ownerships, and fire was a major cause of that mortality. This finding was consistent with an earlier finding [59] of a modest but statistically significant recent decline in black oak basal area (particularly in both small and very large trees) on national forest lands throughout the entire range of the species.

Our hypothesis that shade tolerance would explain trends was consistent with the finding that three shade-tolerant species increased in basal area (Figure 6). However, the two shade-intolerant species other than black oak, white oak, and madrone did not show similar declines. This result suggests that characteristics other than shade intolerance are influencing these trends. One possibility is that fires have affected areas where black oak is relatively more dominant than other species, particularly the Sierra Nevada, Klamath, and California Coast Range ecoregions, which altogether 
contain $92 \%$ of the basal area of the species (Supplemental Table S1). These three regions had the highest rates of fire mortality (over 1\%/year; Table 2). Miller and Safford [79] reported significant increases in area burned by high severity fires within the Sierra Nevada, Modoc Plateau and southern Cascades region in yellow pine and mixed-conifer forests from 1984 to 2010. A similar study in northwestern California (including parts of the Klamath, the northern California Coast Range, and part of the southern Cascade Range ecoregions) reported that total burned area strongly increased from 1987 to 2008; even though the percentage burned at high severity did not increase, their results indicate increases in total area burned at high severity [80]. By contrast, a third recent study in Oregon (including the Oregon Coast Range and Western Cascades) [81] found only a small increase in total area burned and no increase in proportion burned at high severity from 1985 to 2010. Those results suggest that increases in wildfire-caused mortality are presently a greater threat to hardwoods in California. However, vulnerability varies by species, even within those regions. For example, canyon live oak has experienced a net increase, despite the fact that it is more sensitive to fire, and it predominates in inland California ecoregions that did experience considerable fire mortality. That species may be able to compensate for fire-related losses by growing in more shaded conditions and on harsher sites that have not burned severely in recent wildfires.

Our results demonstrate the value of indicators beyond overall basal area, tree densities, or species distributions to inform forest planning and monitoring. For example, the three-period analysis suggested a decline in the basal area of very large black oaks, while the overall basal area was relatively stable. Although the previous habitat modeling for fisher has relied heavily on overall basal areas, large and very large trees appear disproportionately important. In addition, because crown condition is an important driver of fruit production, increases in the basal area of trees that are not in dominant crown conditions may not necessarily result in increased productivity. Consequently, measures of crown condition, especially for large trees, may be important leading indicators. The declines in the more open crown condition classes across species suggest that these forests are widely becoming more densely canopied, which is consistent with expectations that hardwoods might decline [3]. However, the decline in basal area among open-grown and dominant trees might also reflect changes in how field crews categorized dominant and co-dominant classes between sampling periods. That more trees were being classified as co-dominant would explain why basal area in "overstory" black oaks appeared to increase from time 2 to time 3, even while full-crowned black oaks declined. However, the decline in full-crown trees was more pronounced for all of the hardwood species than it was for white fir, which suggests that there may be an ecological dimension to this trend. Evaluation of the next panel of inventory data would test whether this a real and continuing ecological trend, or a transient artifact of shifting field protocols.

As FIA sampling extends into the next period of tree remeasurement, trends may become clearer, especially as the effects of recent very large wildfires become more evident. On the other hand, broad-scale drought and bark beetle epidemics, particularly in the southern Sierra Nevada, have tended to reduce conifer trees much more than black oak [82]. Where such conifer mortality unfolds, hardwoods might enjoy gains [83] that offset declines. This complicated interplay between species' interactions and disturbances make it difficult to predict net trends during rapid climatic change.

\subsection{Strategies and Tactics Conserving Large Hardwood Trees}

Conservation efforts for hardwoods have already been initiated on national forests. For example, in the Sierra Nevada, planting of conifer trees is restricted to within $6 \mathrm{~m}$ of hardwood crowns, under the Sierra Nevada Forest Plan amendment [8]. In Oregon, treatments have been implemented to clear conifers from the crowns of white oaks [63]. However, in isolated cases, such as the southernmost stand of Pacific madrone, managers have also recommended retaining a conifer overstory to sustain favorable micro-site conditions [84].

Many of the strategies and tactics to promote large hardwoods have been guided by tribal traditional knowledge to promote food, spiritual values, and habitat for valued wildlife [6]. 
In pre-colonial times, tribal agroforestry systems across the study region facilitated and fostered site conditions that promoted large trees with full, mushroom-shaped crowns, which were more beneficial for tribal harvesters because they had low branches to facilitate harvesting, as well as increased fruit production [17]. Traditional practices included burning forest patches to promote acorn production and other food plants, as well as to enhance habitat for game animals such as deer and elk. To address current tribal goals, the cultivation and conservation of large trees may be prioritized in specially managed stewardship areas that center on former gathering areas and remnant groves of large hardwoods [59] (Figure 1).

Frequent burning may be an important strategy for promoting large trees and basal cavities [8], especially if precautions can be taken to avoid the losses of legacy trees. Due to the sensitivity of hardwoods to fire, promoting large hardwoods in the near term may depend upon removing or girdling competing conifers and reducing fuel loads mechanically. Accumulations of fuels (especially conifer litter and small trees) allow flames to scorch trees higher on their stems and enter existing stem cavities (Figure 11). Such damage often results in top-kill, and it may reduce the potential for forming and sustaining enclosed cavities [8]. In addition to removing conifers, tactics to protect legacy hardwood trees from wildfires and prescribed burning include raking fuels away from boles of large legacy trees [8], cutting lower limbs to reduce potential for crown fire, burning off lichens hanging on large hardwood branches prior to prescribed burning, and using tree-centered firing [85]. Because shrubs in the understory can intensify fires in white oak woodlands [57] and potentially other hardwood stands, site preparation to reduce oak mortality could include treatments to reduce shrub continuity and to promote grasses or other herbaceous species that facilitate low-intensity fire spread [11]. Collectively, such measures could conserve legacy hardwoods by reducing fire scorching and mortality.

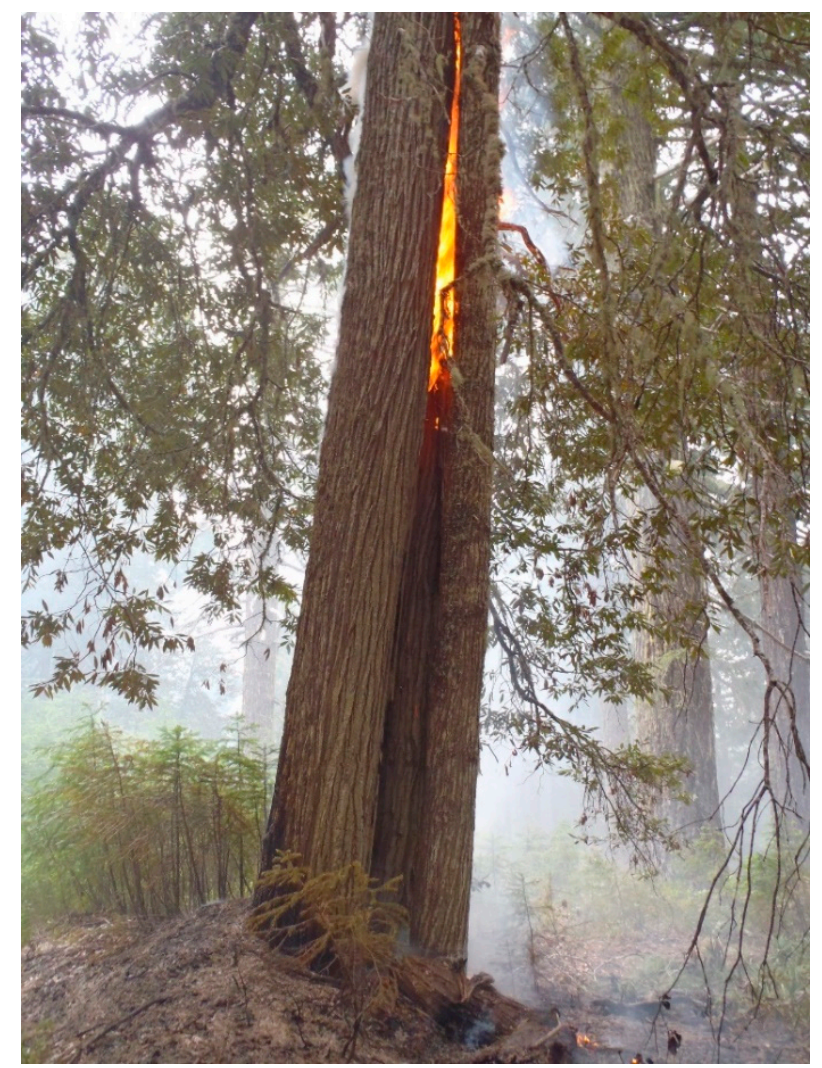

Figure 11. During a prescribed burn in June 2017, fire entered the cavity of this large chinquapin tree, which compromised its integrity (Photo credit: Frank K. Lake). 


\section{Conclusions}

Our results demonstrate how forest inventory data can be used to evaluate trends, the impact of interventions, and potential effects on benefits that these legacy trees have long provided. Our findings of current trends from recent FIA data did not find that the basal areas of eight of the most important large hardwood species, and large trees in particular, were declining overall, with a large region of southwestern Oregon and California, including the California Coast ecoregion where P. ramorum is killing many of these trees. However, some indicators suggested modest downward trends in black oak, particularly on national forest lands in inland parts of California, where fires have been a major cause of mortality. Because black oak appears to be the most vulnerable of these important hardwoods, and because it ranges across much of California, it could be a particularly useful and sensitive indicator of trends across the state. We also found significant declines in large full-crowned hardwoods, which are particularly important for fruit production and wildlife habitat quality. However, that finding may have reflected changes in protocols that are used to classify trees as dominant versus co-dominant. This kind of analysis will become more powerful as more inventory panels are completed, and it will be important to effectively monitor trends across the region. This information can help land managers and tribes in the region to conserve, restore, and monitor large, centuries-old hardwood trees with full crowns. Strategies to conserve these legacy trees may be particularly important within interior regions of California to offset losses from wildfires.

Supplementary Materials: The following are available online at http:/ /www.mdpi.com/1999-4907/9/10/651/s1, Figure S1: Three-period basal area change by ecoregion (NFS and private lands). Figure S2: Three-period basal area change by ownership. Figure S3: Basal area changes on undisturbed plots by crown class group. Table S1: Basal area by ecoregion section at time 2 . Table S2: Annual rate of basal area change $\left(\mathrm{m}^{2} \mathrm{year}^{-1}\right)$ on disturbed plots by disturbance type.

Author Contributions: Conceptualization, J.W.L.; Formal analysis, J.W.L. and A.G.; Methodology, J.W.L. and A.G.; Visualization, J.W.L., A.G. and F.K.L.; Writing—original draft, J.W.L. and A.G.; Writing-review \& editing, J.W.L., A.G. and F.K.L.

Funding: This research received no external funding.

Acknowledgments: This analysis would not have been possible without the efforts of many dedicated crew members who collected data in the field, and people who compiled and reported data to make the FIA datasets available. We also thank Carl Skinner, research geographer emeritus, for providing a constructive review of an early draft of the manuscript and other insights, and Jim Steed, with the Forest Inventory and Analysis program, for insights into field measurements.

Conflicts of Interest: The authors declare no conflict of interest.

\section{References}

1. Taylor, A.H.; Skinner, C.N. Spatial patterns and controls on historical fire regimes and forest structure in the Klamath Mountains. Ecol. Appl. 2003, 13, 704-719. [CrossRef]

2. McShea, W.J.; Healy, W.M.; Devers, P.; Fearer, T.; Koch, F.H.; Stauffer, D.; Waldon, J. Forestry Matters: Decline of Oaks Will Impact Wildlife in Hardwood Forests. J. Wildl. Manag. 2007, 71, 1717-1728. [CrossRef]

3. McComb, B.C.; Spies, T.A.; Olsen, K.A. Sustaining biodiversity in the Oregon Coast Range: Potential effects of forest policies in a multi-ownership province. Ecol. Soc. 2007, 12, art29. [CrossRef]

4. Hagar, J.C. Wildlife species associated with non-coniferous vegetation in Pacific Northwest conifer forests: A review. For. Ecol. Manag. 2007, 246, 108-122. [CrossRef]

5. Long, J.W.; Lake, F.K. Escaping a socioecological trap through tribal stewardship on national forest lands in the Pacific Northwest, USA. Ecol. Soc. 2018, 23, art10. [CrossRef]

6. Bowcutt, F. Tanoak landscapes: Tending a Native American nut tree. Madrono 2013, 60, 64-86. [CrossRef]

7. McGregor, R.R.; Sakalidis, M.L.; Hamelin, R.C. Neofusicoccum arbuti: A hidden threat to Arbutus menziesii characterized by widespread latent infections and a broad host range. Can. J. Plant Pathol. 2016, 38, 70-81. [CrossRef] 
8. $\quad$ Long, J.W.; Anderson, M.K.; Quinn-Davidson, L.N.; Goode, R.W.; Lake, F.K.; Skinner, C.N. Restoring California Black Oak Ecosystems to Promote Tribal Values and Wildlife; U.S. Department of Agriculture, Forest Service, Pacific Southwest Research Station: Albany, CA, USA, 2016.

9. Coops, N.C.; Waring, R.H. Estimating the vulnerability of fifteen tree species under changing climate in Northwest North America. Ecol. Model. 2011, 222, 2119-2129. [CrossRef]

10. Case, M.J.; Lawler, J.J. Relative vulnerability to climate change of trees in western North America. Clim. Chang. 2016, 136, 367-379. [CrossRef]

11. Nemens, D.G.; Varner, J.M.; Kidd, K.R.; Wing, B. Do repeated wildfires promote restoration of oak woodlands in mixed-conifer landscapes? For. Ecol. Manag. 2018, 427, 143-151. [CrossRef]

12. Cocking, M.I.; Varner, J.M.; Sherriff, R.L. California black oak responses to fire severity and native conifer encroachment in the Klamath Mountains. For. Ecol. Manag. 2012, 270, 25-34. [CrossRef]

13. Hammett, E.J.; Ritchie, M.W.; Berrill, J.-P. Resilience of California black oak experiencing frequent fire: Regeneration following two large wildfires 12 years apart. Fire Ecol. 2017, 13, 91-103. [CrossRef]

14. Filipe, J.A.; Cobb, R.C.; Meentemeyer, R.K.; Lee, C.A.; Valachovic, Y.S.; Cook, A.R.; Rizzo, D.M.; Gilligan, C.A. Landscape epidemiology and control of pathogens with cryptic and long-distance dispersal: Sudden oak death in northern Californian forests. PLoS Comp. Biol. 2012, 8, e1002328. [CrossRef] [PubMed]

15. Lofroth, E.; Raley, C.; Higley, J.; Truex, R.; Yaeger, J.; Lewis, J.; Happe, P.; Finley, L.; Naney, R.; Hale, L. Conservation of Fishers (Martes pennanti) in South-Central British Columbia, Western Washington, Western Oregon, and California-Volume I: Conservation Assessment; USDI Bureau of Land Management: Denver, CO, USA, 2010.

16. Long, J.W.; Lake, F.K.; Lynn, K.; Viles, C. Tribal Ecocultural Resources and Engagement; USDA Forest Service, Pacific Northwest Research Station: Portland, OR, USA, 2018.

17. Anderson, M.K. Indigenous Uses Management, and Restoration of Oaks of the Far Western United States; NRCS National Plant Data Center: Washington, DC, USA, 2007.

18. Baumhoff, M.A. California Athabascan groups. Anthr. Rec. 1958, 16, 157-238.

19. Kniffen, F.B. Achomawi geography. Univ. Calif. Publ. Am. Archaeol. Ethnol. 1928, 23, 297-332.

20. Kroeber, A.L.; Gifford, E.W. World renewal: A cult system of native northwest California. Anthr. Rec. 1949, 13, 1-156.

21. Du Bois, C. Wintu ethnography. Univ. Calif. Publ. Am. Archaeol. Ethnol. 1935, 36, 1-148.

22. Bunnell, F.L.; Kremsater, L.L.; Wind, E. Managing to sustain vertebrate richness in forests of the Pacific Northwest: Relationships within stands. Environ. Rev. 1999, 7, 97-146. [CrossRef]

23. Wu, J.X.; Siegel, R.B.; Loffland, H.L.; Tingley, M.W.; Stock, S.L.; Roberts, K.N.; Keane, J.J.; Medley, J.R.; Bridgman, R.; Stermer, C. Diversity of great gray owl nest sites and nesting habitats in California. J. Wildl. Manag. 2015, 79, 937-947. [CrossRef]

24. Lindenmayer, D.B. Integrating forest biodiversity conservation and restoration ecology principles to recover natural forest ecosystems. New For. 2018. [CrossRef]

25. Wasyl, J. Uncle oak: The giant of Palomar Mountain. Int. Oaks 2011, 22, 100-103.

26. Duckworth, J. Remembering Fallen Champion Trees; American Forests: Washington, DC, USA, 2016. Available online: http:/ / www.americanforests.org/blog/remembering-fallen-champion-trees/ (accessed on 1 April 2018).

27. Cocking, M.I.; Varner, J.M.; Knapp, E.E. Long-term effects of fire severity on oak-conifer dynamics in the southern Cascades. Ecol. Appl. 2014, 24, 94-107. [CrossRef] [PubMed]

28. Baker, W.L. Historical forest structure and fire in Sierran mixed-conifer forests reconstructed from General Land Office survey data. Ecosphere 2014, 5, 1-70. [CrossRef]

29. Cocking, M.I.; Varner, J.M.; Engber, E.A. Conifer Encroachment in California Oak Woodlands; U.S. Department of Agriculture, Forest Service, Pacific Southwest Research Station: Albany, CA, USA, 2015.

30. Crawford, J.N.; Mensing, S.A.; Lake, F.K.; Zimmerman, S.R. Late Holocene fire and vegetation reconstruction from the western Klamath Mountains, California, USA: A multi-disciplinary approach for examining potential human land-use impacts. Holocene 2015, 25, 1341-1357. [CrossRef]

31. Taylor, A.H.; Trouet, V.; Skinner, C.N.; Stephens, S. Socioecological transitions trigger fire regime shifts and modulate fire-climate interactions in the Sierra Nevada, USA, 1600-2015 CE. Proc. Natl. Acad. Sci. USA 2016, 113, 13684-13689. [CrossRef] [PubMed]

32. Anderson, K. Tending the Wild: Native American Knowledge and the Management of California's Natural Resources; University of California Press: Berkeley, CA, USA, 2005. 
33. Abrams, M.D.; Nowacki, G.J. Native Americans as active and passive promoters of mast and fruit trees in the eastern USA. Holocene 2008, 18, 1123-1137. [CrossRef]

34. Chamberlain, J.L.; Emery, M.R.; Patel-Weynand, T. Assessment of Nontimber Forest Products in the United States under Changing Conditions; USDA Forest Service Southern Research Station: Asheville, NC, USA, 2018.

35. Chamberlain, J.L.; Prisley, S.; McGuffin, M. Understanding the relationships between American ginseng harvest and hardwood forests inventory and timber harvest to improve co-management of the forests of eastern United States. J. Sustain. For. 2013, 32, 605-624. [CrossRef]

36. Emery, M.R.; Wrobel, A.; Hansen, M.H.; Dockry, M.; Moser, W.K.; Stark, K.J.; Gilbert, J.H. Using traditional ecological knowledge as a basis for targeted forest inventories: Paper birch (Betula papyrifera) in the US Great Lakes region. J. For. 2014, 112, 207-214. [CrossRef]

37. Vance, N.; Gray, A.; Haberman, B. Assessment of Western Oregon Forest Inventory for Evaluating Commercially Important Understory Plants; USDA Forest Service Pacific Northwest Research Station: Portland, OR, USA, 2002.

38. Christensen, G.A.; Waddell, K.L.; Stanton, S.M.; Kuegler, O. California's Forest Resources: Forest Inventory and Analysis, 2001-2010; USDA Forest Service, Pacific Northwest Research Station: Portland, OR, USA, 2016.

39. McIntyre, P.J.; Thorne, J.H.; Dolanc, C.R.; Flint, A.L.; Flint, L.E.; Kelly, M.; Ackerly, D.D. Twentieth-century shifts in forest structure in California: Denser forests, smaller trees, and increased dominance of oaks. Proc. Natl. Acad. Sci. USA 2015, 112, 1458-1463. [CrossRef] [PubMed]

40. Dolanc, C.R.; Safford, H.D.; Thorne, J.H.; Dobrowski, S.Z. Changing forest structure across the landscape of the Sierra Nevada, CA, USA, since the 1930s. Ecosphere 2014, 5, art101. [CrossRef]

41. Lutz, J.A.; van Wagtendonk, J.W.; Franklin, J.F. Twentieth-century decline of large-diameter trees in Yosemite National Park, California, USA. For. Ecol. Manag. 2009, 257, 2296-2307. [CrossRef]

42. Zielinski, W.J.; Gray, A.N. Using routinely collected regional forest inventory data to conclude that resting habitat for the fisher (Pekania pennanti) in California is stable over 20 years. For. Ecol. Manag. 2018, 409, 899-908. [CrossRef]

43. Zielinski, W.J.; Truex, R.L.; Dunk, J.R.; Gaman, T. Using forest inventory data to assess fisher resting habitat suitability in California. Ecol. Appl. 2006, 16, 1010-1025. [CrossRef]

44. Zielinski, W.J.; Dunk, J.R.; Gray, A.N. Estimating habitat value using forest inventory data: The fisher (Martes pennanti) in northwestern California. For. Ecol. Manag. 2012, 275, 35-42. [CrossRef]

45. Waddell, K.L.; Barrett, T.M. Oak Woodlands and other Hardwood Forests of California, 1990s; USDA Forest Service, Pacific Northwest Research Station: Portland, OR, USA, 2005.

46. USDA Forest Service. Draft Revised Land Management Plan for the Sierra National Forest; USDA Forest Service, Pacific Southwest Region, Sierra National Forest: Clovis, CA, USA, 2016.

47. McDonald, P.M.; Tappeiner, J.C. California's Hardwood Resource: Seeds, Seedlings, and Sprouts of Three Important Forest-Zone Species; U.S. Department of Agriculture, Forest Service, Pacific Southwest Research Station: Albany, CA, USA, 2002.

48. Gucker, C.L. Quercus garryana; USDA Forest Service, Rocky Mountain Research Station: Fort Collins, CO, USA. Available online: https:/ / www.fs.fed.us/database/feis/plants/tree/quegar/all.html (accessed on 30 July 2018).

49. Tollefson, J.E. Quercus chrysolepis; USDA Forest Service, Rocky Mountain Research Station: Fort Collins, CO, USA. Available online: https:/ / www.fs.fed.us/database/feis/plants/tree/quechr/all.html (accessed on 1 May 2018).

50. Meyer, R. Chrysolepis chrysophylla; USDA Forest Service, Rocky Mountain Research Station: Fort Collins, CO, USA. Available online: https:/ /www.fs.fed.us/database/feis/plants/tree/chrchr/all.html (accessed on 30 July 2018).

51. Reeves, S.L. Arbutus menziesii; USDA Forest Service, Rocky Mountain Research Station: Fort Collins, CO, USA. Available online: https:/ / www.fs.fed.us/database/feis/plants/tree/arbmen/all.html (accessed on 30 July 2018).

52. Fryer, J.L. Acer macrophyllum, bigleaf maple; USDA Forest Service, Rocky Mountain Research Station: Fort Collins, CO, USA. Available online: https:/ /www.fs.fed.us/database/feis/plants/tree/acemac/all.html (accessed on 1 May 2018). 
53. Howard, J.L. Umbellularia californica; USDA Forest Service Rocky Mountain Research Station: Fort Collins, CO, USA. Available online: https:/ / www.fs.fed.us/database/feis/plants/tree/umbcal/all.html (accessed on 1 May 2018).

54. Niemiec, S.S.; Ahrens, G.R.; Willits, S.; Hibbs, D.E. Hardwoods of the Pacific Northwest; Research Contribution; Oregon State University: Corvallis, OR, USA, 1995.

55. Frankel, S. USDA Forest Service, Pacific Southwest Research Station, Albany, CA, USA. Personal communication, 2018.

56. Bolsinger, C.L. The Hardwoods of California's Timberlands, Woodlands, and Savannas; USDA Forest Service, Pacific Northwest Research Station: Portland, OR, USA, 1988.

57. Little, E.L., Jr. Conifers and Important Hardwoods; Miscellaneous Publication 1186; USDA: Washington DC, USA, 1971.

58. Little, E.L., Jr. Minor Western Hardwoods; Miscellaneous Publication 1314; USDA: Washington, DC, USA, 1976.

59. McDonald, P.M. Chrysolepis Hjelmqvist. In Silvics of North America; Burns, R.M., Honkala, B.H., Eds.; USDA Forest Service: Washington, DC, USA, 1990; pp. 404-406.

60. Peter, D.; Harrington, C. Site and tree factors in Oregon white oak acorn production in western Washington and Oregon. Northwest Sci. 2002, 76, 189-201.

61. Devine, W.D.; Harrington, C.A. Restoration release of overtopped Oregon white oak increases 10-year growth and acorn production. For. Ecol. Manag. 2013, 291, 87-95. [CrossRef]

62. Long, J.W.; Goode, R.W.; Gutteriez, R.J.; Lackey, J.J.; Anderson, M.K. Managing California black oak for tribal ecocultural restoration. J. For. 2017, 115, 426-434. [CrossRef]

63. Yaeger, J.S. Habitat at Fisher Resting Sites in the Klamath Province of Northern California. Master's Thesis, Humboldt State University, Arcata, CA, USA, May 2005.

64. Aubry, K.B.; Raley, C.M.; Buskirk, S.W.; Zielinski, W.J.; Schwartz, M.K.; Golightly, R.T.; Purcell, K.L.; Weir, R.D.; Yaeger, J.S. Meta-analyses of habitat selection by fishers at resting sites in the Pacific coastal region. J. Wildl. Manag. 2013, 77, 965-974. [CrossRef]

65. North, M.; Steger, G.; Denton, R.; Eberlein, G.; Munton, T.; Johnson, K. Association of weather and nest-site structure with reproductive success in California spotted owls. J. Wildl. Manag. 2000, 64, 797-807. [CrossRef]

66. Devine, W.D.; Harrington, C.A. Changes in Oregon white oak (Quercus garryana Dougl. ex Hook.) following release from overtopping conifers. Trees 2006, 20, 747-756. [CrossRef]

67. Arno, S.F. Fire in Western Forest Ecosystems; USDA Forest Service Rocky Mountain Research Station: Fort Collins, CO, USA, 2000.

68. Fonda, R. Postfire response of red alder, black cottonwood, and bigleaf maple to the Whatcom Creek fire, Bellingham, Washington. Northwest Sci. 2001, 75, 25-36.

69. Dale, V.H.; Hemstrom, M.; Franklin, J. Modeling the long-term effects of disturbances on forest succession, Olympic Peninsula, Washington. Can. J. For. Res. 1986, 16, 56-67. [CrossRef]

70. Cobb, R.C.; Filipe, J.A.N.; Meentemeyer, R.K.; Gilligan, C.A.; Rizzo, D.M. Ecosystem transformation by emerging infectious disease: Loss of large tanoak from California forests. J. Ecol. 2012, 100, 712-722. [CrossRef]

71. Bechtold, W.A.; Patterson, P.L. The Enhanced Forest Inventory and Analysis Program-National Sampling Design and Estimation Procedures; USDA Forest Service, Southern Research Station: Asheville, NC, USA, 2005.

72. Eyre, F.H. Forest Cover Types of the United States and Canada; Society of American Foresters: Washington, DC, USA, 1980.

73. McNab, W.H.; Cleland, D.T.; Freeouf, J.A.; Keys Jr, J.E.; Nowacki, G.J.; Carpenter, C.A. Description of Ecological Subregions: Sections of the Conterminous United States; USDA Forest Service: Washington, DC, USA, 2007.

74. LANDFIRE. Fire Regime Groups. USDI, Geological Survey. Available online: https://landfire.gov/frg.php (accessed on 31 August 2018).

75. Spencer, W.D.; Sawyer, S.C.; Romsos, H.L.; Zielinski, W.J.; Sweitzer, R.A.; Thompson, C.M.; Purcell, K.L.; Clifford, D.L.; Cline, L.; Safford, H.D.; et al. Southern Sierra Nevada Fisher Conservation Assessment; Conservation Biology Institute: Portland, OR, USA, 2015.

76. USDA Forest Service. Inventory Data. Available online: https://www.fs.fed.us/pnw/rma/fia-topics/ inventory-data/index.php (accessed on 31 August 2018). 
77. Scott, C.T.; Bechtold, W.A.; Reams, G.A.; Smith, W.D.; Westfall, J.A.; Hansen, M.H.; Moisen, G.G. Sample-Based Estimators Used by the Forest Inventory and Analysis National Information Management System; USDA Forest Service, Southern Research Station: Asheville, NC, USA, 2005.

78. Tappeiner, J.; McDonald, P.M.; Roy, D.F. Lithocarpus densiflorus (Hook. \& Arn.) Rehd. Tanoak. In Silvics of North America; Burns, R.M., Honkala, B.H., Eds.; USDA: Washington, DC, USA, 1990; pp. 417-425.

79. Miller, J.D.; Safford, H.D. Trends in wildfire severity 1984-2010 in the Sierra Nevada, Modoc Plateau, and southern Cascades, California, USA. Fire Ecol. 2012, 8, 41-57. [CrossRef]

80. Miller, J.D.; Skinner, C.N.; Safford, H.D.; Knapp, E.E.; Ramirez, C.M. Trends and causes of severity, size, and number of fires in northwestern California, USA. Ecol. Appl. 2012, 22, 184-203. [CrossRef] [PubMed]

81. Reilly, M.J.; Dunn, C.J.; Meigs, G.W.; Spies, T.A.; Kennedy, R.E.; Bailey, J.D.; Briggs, K. Contemporary patterns of fire extent and severity in forests of the Pacific Northwest, USA (1985-2010). Ecosphere 2017, 8, e01695. [CrossRef]

82. Paz-Kagan, T.; Brodrick, P.G.; Vaughn, N.R.; Das, A.J.; Stephenson, N.L.; Nydick, K.R.; Asner, G.P. What mediates tree mortality during drought in the southern Sierra Nevada? Ecol. Appl. 2017, 27, 2443-2457. [CrossRef] [PubMed]

83. Stephens, S.L.; Collins, B.M.; Fettig, C.J.; Finney, M.A.; Hoffman, C.M.; Knapp, E.E.; North, M.P.; Safford, H.; Wayman, R.B. Drought, tree mortality, and wildfire in forests adapted to frequent fire. Bioscience 2018, 68, 77-88. [CrossRef]

84. USFS. Rim Fire Restoration Environmental Impact Statement; Stanislaus National Forest: Sonora, CA, USA, 2016.

85. Weatherspoon, C.P.; Almond, G.A.; Skinner, C.N. Tree-centered spot firing-a technique for prescribed burning beneath standing trees. West. J. Appl. For. 1989, 4, 29-31.

(C) 2018 by the authors. Licensee MDPI, Basel, Switzerland. This article is an open access article distributed under the terms and conditions of the Creative Commons Attribution (CC BY) license (http:/ / creativecommons.org/licenses/by/4.0/). 